\title{
LA FUERZA MAYOR COMO ATEMPERACIÓN DEL CARÁCTER SANCIONATORIO DE LA CADUCIDAD: UN POSIBLE ANTÍDOTO AL CURARE DE LA PUESTA EN MARCHA DE LA PRETENSIÓN CONTENCIOSO- ADMINISTRATIVA*
}

\author{
Julián Suárez Bohórquez** \\ Recibido: Mayo 17 de 2017 \\ Aprobado: Agosto 23 de 2017
}

\begin{abstract}
RESUMEN
En el sistema de medios de control contencioso-administrativos, la caducidad es un fenómeno inexorable que extingue la pretensión jurídico-procesal contra la Administración, fundamentada en la inacción culposa del demandante ante el paso del tiempo.
\end{abstract}

Al igual que ocurre en otras latitudes, se trata de una protección de la legalidad y de la seguridad jurídica frente a las situaciones jurídicas particulares creadas por actos u omisiones de la Administración. Sin embargo, en Colombia se han dado soluciones jurisprudenciales para justificar atemperaciones o aplicaciones rigurosas de la figura, que no tienen asidero legal razonable alguno, y que constituyen, a veces, interpretaciones en contra del debido proceso sustantivo y de la efectividad de los derechos de los justiciables. Con base en los desarrollos del derecho belga, y con lo propuesto ya por el Consejo de Estado en ciertas ocasiones, el artículo propone a la fuerza mayor como

\footnotetext{
* Agradezco enormemente al abogado mexicano Óscar Torres Rodríguez, doctorante en derecho de las FacultésUniversitaires Saint-Louis (Bélgica), por sus valiosos aportes a este escrito.

** Abogado de la Pontificia Universidad Javeriana. Especialista en Instituciones Jurídico-Procesales y Magíster en Derecho Administrativo de la Universidad Nacional de Colombia. Candidato del Master en DroitfinalitéÉtat et Europe de la UniversitéCatholique de Louvain (Bélgica). Consultor y litigante en derecho administrativo.
} 
límite racional a la perentoriedad de la caducidad, en tanto principio general del derecho de origen legal.

Palabras clave: Caducidad, prescripción, medios de control contencioso-administrativos, pretensiones contencioso-administrativas, fuerza mayor.

\title{
FORCE MAJEURE AS MITIGATION OF THE SANCTION OF THE EXPIRATION: A POSSIBLE ANTIDOTE TO THE IMPLEMENTATION OF THE CONTENTIOUS- ADMINISTRATIVE CLAIM
}

\begin{abstract}
Within the current administrative law litigation rules, dismissal for want of prosecution due to forfeiture of the claim is an inevitable phenomenon that extinguishes any right to seek affirmative relief, based on passivity of the plaintiff to appear for trial. As it happens in other latitudes, this type of dismissal is in fact a protection of rule of law and legal security against legal situations created by acts or omissions of the administration. Nevertheless, in Colombia, some State Council rulings have used unsettling and unreasonable arguments to justify either attenuation or rigour in the enforcement of dismissal for want of prosecution due to forfeiture of the claim.

However, in Colombia there have been jurisprudential solutions that justify mitigation or rigorous applications of this concept, which have no reasonable legal foundation and which sometimes constitute interpretations against due process and the effectiveness of the rights of the defendants. Based on the developments of Belgian law and Council of State rulings, this article proposes force majeure as a rational limit to the dismissal for want of prosecution due to forfeiture of the claim, as a general principle of law.
\end{abstract}

Keywords: expiration, administrative litigation law , contentiousadministrative claims, force majeure.

A FORÇA MAIOR COMO MODERADOR DO CARÁTER SANCIONATÓRIO DA CADUCIDADE: UM POSSÍVEL ANTIDOTO COMO CURA DA IMPLEMENTAÇÃO DA PRETENSÃO CONTENCIOSO-ADMINISTRATIVA 


\section{RESUMO}

No sistema de meios de controle contencioso-administrativos, a caducidade é um fenômeno inexorável que extingue a pretensão jurídico-processual contra a Administração, baseada na inação culposa do demandante perante ao passo do tempo.

Assim como acontece em outras latitudes, é uma proteção da legalidade e da segurança jurídica perante às situações jurídicas particulares criadas por atos ou omissões da Administração. No entanto, na Colômbia foram dadas soluções jurisprudenciais para justificar moderações ou aplicações rigorosas da figura, que não possuem base jurídica razoável e que às vezes constituem interpretações contra o devido processo e a eficácia dos direitos dos réus. Com base na evolução do direito belga e com o proposto já pelo Conselho de Estado em certas ocasiões, o artigo propõe à força maior como limite racional ao caráter imperativo da caducidade, como princípio geral do direito de origem legal.

Palavras chave: Caducidade, prescrição, meios de controle Contencioso-Administrativo, pretenções contencioso-administrativas, força maior.

\section{INTRODUCCIÓN}

En el derecho continental europeo -particularmente, en los sistemas jurídicos de tradición francesa- existe una distinción entre las dos siguientes figuras jurídicas: por un lado, la caducidad de los derechos y acciones, y por otro lado, su prescripción. En un primer nivel, que podría llamarse de derecho privado común, contrario a lo que se ha dicho por algún sector de la doctrina nacional, la caducidad reviste una naturaleza sancionatoria por un comportamiento culposo de una parte en una relación jurídica, mientras que la prescripción ostenta una naturaleza probatoria - de presunción de pago de una obligación- en calidad de excepción. En un segundo nivel, propio del derecho administrativo, las demandas en anulación de actos administrativos o en ejercicio de los recursos por desvío de poder, al igual que las consecuentes reparaciones a que haya lugar, están sujetas a términos sancionados con caducidad, sin que haya cabida para la prescripción extintiva frente a su ejercicio efectivo.

Esa distinción existe hoy, por vía del derecho privado común y de leyes especiales, en el derecho administrativo colombiano, tanto en su parte 
sustancial como en su aspecto procesal. Es posible constatar que existe un relativo consenso tanto en la jurisprudencia como en la doctrina nacional acerca de las condiciones de validez y los efectos jurídicos de ambas figuras en esa especialidad jurídica, donde unas y otras se han aplicado a algunos derechos y a las antiguas acciones -hoy pretensiones o medios de control-. No obstante, teniendo en cuenta que se trata, al igual que las demás figuras de nuestro derecho, de nociones importadas de otros derechos extranjeros - como lo fueron en su momento el derecho francés, el derecho español y el derecho italiano en el antiguo CCA, y hoy, el derecho español y el derecho argentino en el CPACA-, en el sentido amplio -lo que incluye sin duda disposiciones jurídicas, jurisprudencia y doctrina-, vale la pena efectuar algunas precisiones en cuanto al concepto, a las condiciones de validez y a los efectos de la prescripción y de la caducidad.

Esto es de capital importancia tratándose de los efectos devastadores de la caducidad frente a la puesta en marcha de las pretensiones contencioso-administrativas. Hasta el momento, aparte de la suspensión del término de caducidad, no existe ninguna alternativa de justicia, dentro del ordenamiento jurídico, que permita atemperar de forma proporcionada y razonable los rigurosos efectos de la caducidad. Por eso, proponer una lectura diferente de estas nociones jurídicas desde un ordenamiento jurídico foráneo, además de colmar lagunas que podrían presentarse en el derecho nacional, permite aportar un nuevo elemento consagrado en el derecho común colombiano desde antaño, a considerar por el juez contencioso administrativo al momento de pronunciarse sobre la admisión de la demanda o sobre una eventual excepción de caducidad. Con ello, dada la perentoriedad de la defensa de la seguridad jurídica que justifica la institución de la caducidad, podría evitarse que se llegue a soluciones inequitativas y desproporcionadas, no sólo para los intereses litigiosos de los administrados, cuando haya razones suficientes que hayan imposibilitado el ejercicio en tiempo del respectivo medio de control, sino para la Nación misma, cuando sea ésta la que busque la tutela judicial efectiva ante los jueces y Tribunales contencioso-administrativas.

Para el propósito que viene de enunciarse, se han escogido el derecho civil y el derecho administrativo de Bélgica, como tertiumcomparationis. Tales desarrollos legales extranjeros serán, a su vez, reforzados con algunos tratamientos de la problemática extraídos del derecho francés. En estos ordenamientos jurídicos, en los que se ha reconocido la imposibilidad de interrumpir o de suspender los términos de caducidad salvo excepción legal expresa, se han pensado soluciones 38 
originales para atemperar los efectos inexorablemente paralizantes de los términos de caducidad, de cara al ejercicio de las pretensiones contencioso-administrativas.

En nuestro derecho, por el contrario, de manera bastante original también, se ha decidido optar por matizar el momento de inicio del cómputo del término de caducidad. Así, se ha asumido -de una manera que nos causa extrañeza- que los términos de caducidad de las pretensiones contencioso-administrativas, por ser de orden público, interesan automáticamente al interés general y son irrenunciables. De la misma forma, tales soluciones de origen jurisprudencial, aunque particulares, se han aplicado en varias ocasiones de manera demasiado rigurosa al momento de interpretar las normas de cómputo de términos, olvidando así que existen situaciones de hecho ajenas a las partes cuyos efectos no entran dentro de las previsiones normales de aquellas y a los que éstas no pueden razonablemente oponerse.

\section{PRESCRIPCIÓN Y CADUCIDAD: DE LA EXCEPCIÓN DE PRESCRIPCIÓN A LOS DÉLAIS DE FORCLUSIONY A LA RECHTVERWERKING}

Como se aseveró en los párrafos precedentes, la prescripción y la caducidad son percibidas en derecho colombiano como dos instituciones autónomas, cada una con condiciones de validez y efectos jurídicos diferentes. Es frecuente escuchar en el foro aseveraciones como "la prescripción es para los derechos; la caducidad, para las acciones". También a menudo se dice que la diferencia entre una y otra figura es, esencialmente, su posibilidad de ser declarada de oficio por el juez, debido al interés privado o de orden público, según el caso, que estaría de por medio en una y otra. De igual manera, se ha aceptado sin cuestionamiento alguno el carácter irrenunciable de la caducidad, frente a la posibilidad de renunciar a la prescripción. Asimismo, no es menos frecuente oír, a manera de sabiduría jurídica popular, que el efecto de una y otra sería el mismo porque impiden el reclamar un derecho subjetivo en juicio por el paso del tiempo.

No obstante que, en principio, tales apreciaciones serían correctas, se ha afirmado con anterioridad que éstas revelan preconceptos propios de una aproximación superficial de la cuestión (Fonseca Jaramillo, 2004, p. 181 y ss.). En los países donde se ha tratado la temática a fondo por la doctrina, y a los que haremos referencia en estas líneas, también ésta genera no poca controversia. La institución de la caducidad, por ejemplo, 
puede ser confundida con otras instituciones, como la teoría de la apariencia o la extinción de una obligación por desaparición de su objeto. En el derecho belga, la cuestión ha sido tratada por la doctrina como un asunto de prescripción, de renuncias expresas o tácitas y de términos de caducidad. Sin embargo, por la proximidad lingüística que existe entre el castellano y el francés, es necesario distinguir, de entrada, la noción de caducidad en castellano, de la noción de caducité en francés.

Valga la pena tener en cuenta que la expresión caducité (o ongeldigheid, en holandés) no es la misma caducidad en español. La caducité es, en esencia, la extinción de un contrato por ausencia de objeto. La noción fue insertada en Bélgica por la Corte de Casación, en una sentencia de 28 de noviembre de 1980 (Corte de Casación de Bélgica, 1980). Allí se le permitió al arrendador, responsable por su culpa de la pérdida total del inmueble alquilado, de tener por "resuelto" el contrato de arrendamiento, pero sin que pudiera prevalecerse del riesgo de la cosa ni de la de la resolución judicial del contrato con daños y perjuicios del artículo 1184 del Código Civil belga -pues ésta se encuentra reservada sólo a la parte perjudicada con la inejecución del negocio; esto es, el arrendatario-. La decisión en comento fue acogida por la doctrina belga como la introducción a ese derecho de la desaparición del objeto negocial, incluso siendo imputable a la falta de una de las partes, como una causal general de disolución de pleno derecho del mismo (Jafferali, 2016,p. 130-131).

A juicio de la doctrina, dicha institución permite dar respuesta a varias soluciones que se habrían adoptado para ciertos problemas particulares del derecho privado belga. Por ejemplo, el efecto que tendría la muerte de la parte respecto de la cual el contrato se ha celebrado intuito personae, la consecuencia que ocasionaría la entrada en vigor de una ley imperativa o de orden público que generaría la ilegalidad de un contrato durante su existencia y ejecución o también la suerte común que correrían los grupos de contratos o contratos en cascada en caso de disolución de alguno de ellos. En todos esos eventos, la ejecución in natura del contrato se encuentra excluida y que, sin importar la causa de dicha situación, parece irrazonable permitir al acreedor exigir una prestación del deudor que ni siquiera hipotéticamente puede serle solucionada. Se observa cómo la naturaleza misma de las cosas impone constatar esa situación de hecho para considerar la obligación debida y todo el contrato - de ser el caso- como caducos, dejando abierta tan sólo la posibilidad de reclamar eventuales daños y perjuicios si existe una parte culpable responsable de la desaparición del objeto contractual (Jafferali, 2016, p. 123). 
La finalidad misma de la institución, según se ve, permite excluirla de inmediato para lo que aquí nos ocupa: ésta se aplicaría únicamente a los contratos y a los derechos subjetivos que de ellos nacen para cada una de las partes. Es decir, sería estrictamente una figura con un campo de acción delimitado a todo acuerdo de voluntades libre, en la que la "caducidad" de la obligación resulta de la imposibilidad de ejecutar in natura su objeto, apreciado éste según lo pactado entre las partes, sea en razón de un caso fortuito o por cuenta del hecho mismo del acreedor o del deudor, que produce sus efectos de pleno derecho y que constituye un principio general del derecho de carácter dispositivo (Jafferali, 2016, 153-154)(Van Ommeslaghe, Traité de droit civil belge, Tomo II, 2013). A ello hay que agregar que ésta no opera con efecto retroactivo, pues sólo opera desde el momento donde continuar con la ejecución del negocio se hace imposible y que tiene la virtualidad de privar a la obligación, e incluso al contrato, de todo efecto útil o de parte de aquel (Van Ommeslaghe, 2013, p. 649-650).

Claramente, esta caducité no tiene nada que ver con la caducidad de los contratos estatales, como parte de las prerrogativas exorbitantes que la administración pública puede pactar allí. La figura, reglamentada en el artículo 18 de la Ley 80 de 1993 y en el artículo 86 de la Ley 1474 de 2011, según se recordará, permite decretar la terminación unilateral, sin derecho a remuneración alguna, con la posibilidad de que sea el asegurador del contratista que asuma el costo de contratar un tercero que ejecutará el objeto negocial. Ello, para evitar la parálisis grave que se cierne en la prestación de los servicios a cargo de la entidad contratista (Consejo de Estado, 2014).

Ahora bien, la figura jurídica del término de caducidad en derecho colombiano es mucho más cercana de lo que se ha dado en llamar déchéance, délaisfixes o délais de forclusion. La déchéance (hetrechtsverval) o el délai de forclusion (de vervaltermijn), en derecho belga, traducida al castellano, significa también caducidad. En esta versión de la acepción, la caducidad significa, en efecto, la pérdida de un derecho o de una prerrogativa a título de sanción de un comportamiento de su titular juzgado como culposo por la ley. La caducidad, en este sentido, exige siempre la existencia de un texto legal -0 en el caso de las caducidades convencionales, de una cláusula- que la prevea expresamente. Por tanto, tales normas que prevén las caducidades se consideran de interpretación estricta, al ser una punición a una actitud censurable particularmente definida por la ley de quien es titular del derecho o de la prerrogativa en cuestión (Van Ommeslaghe, Rechtsverwerking en afstand van recht, 1979, p. 752-753). 
En concreto, el término de caducidad (délai de forclusiono délaifixe) sería una especie de la caducidad en sentido amplio (déchéance), diferenciada del género "caducidad" en razón de un factor temporal. En el término de caducidad, el titular del derecho caduco sufre los efectos de una sanción por la falta de perfeccionamiento de una formalidad en un término preestablecido, lo que le impide no sólo cumplir con dicha carga en el futuro, sino hacer efectivo su derecho posteriormente. La caducidad es, en cuanto a ella, la pérdida de un derecho resultante de una indignidad, de la incapacidad, del fraude o de la incuria o mala fe. Ejemplo de lo anterior, en el derecho belga, es la caducidad del derecho de conducir prevista por el artículo $38 \S 1$ de la Ley de 19 de marzo de 1968 relativa a la policía de la circulación en carretera ${ }^{1}$ (Bernaert, Tulkens y Vandermeersch, 2016, p. 1107) -que en Bélgica está prevista igualmente como una sanción penal-. Mientras tanto, un ejemplo de término de caducidad lo constituye, en ese mismo ordenamiento, el inciso $2^{\circ}$ del artículo 860 del Código Judicial ${ }^{2}$, donde el incumplimiento de los denominados "término de aceleración" para la interposición de un recurso como la apelación son sancionados so pena de caducidad. Por eso, el carácter eminentemente sancionatorio del término de caducidad no es susceptible de interrupción ni de suspensión alguna, ni mucho menos de pacto en contrario entre las partes, ya que busca punir civilmente un comportamiento tardío, poco diligente, del titular de un derecho. Tal carácter sancionatorio -civilmente hablando- permite que la caducidad pueda ser declarada de oficio por el juez, porque la sanción a la inacción objetivamente culposa del titular de la prerrogativa o del derecho sería de interés general (Rouvière, 2009, p. 7-11).

Con todo, es importante resaltar que en el caso del inciso $2^{\circ}$ del artículo 860 del Código Judicial belga, el inciso $2^{\circ}$ del artículo 700 del mismo Código admite, de igual forma, que si bien el incumplimiento de un término perentorio sancionado con caducidad ha impedido la decisión de fondo respecto de un recurso o de una demanda, la presentación del acto no dejará de producir los efectos de interrupción de la prescripción (Englebert, Boularbah y Van Drooghenbroeck, 2015, p. 245).

Esta figura se opone a lo que en derecho holandés se conoce como rechtsverwerking, o en Francia y en Bélgica francófona como renonciationtacite. En castellano, podría hablarse, entonces, de la

1 De conformidad con esa disposición, el denominado Tribunal de Police puede pronunciar la caducidad o pérdida del derecho a conducir un vehículo motorizado, entre otras causas, si la condena penal es impuesta al infractor por causa de un accidente de conducción imputable a título personal y ésta le ha sido infligida por causa de homicidio o lesiones personales.

2 En esta norma, recientemente reformada por el artículo 22 de la Ley de 19 de octubre de 2015 ("Loipotpourri I"), el Legislador dispone que los términos previstos para la interposición de un recurso son perentorios, so pena de caducidad. 
renuncia tácita a un derecho, en tanto comportamiento que ocasiona su pérdida, por tratarse de un acto que riñe con la buena fe y que exterioriza una apariencia fraudulenta creada en detrimento de un tercero que sufre un perjuicio por dicha causa. Sin embargo, en ese ordenamiento jurídico, la figura del rechtsverwerkingse refiere propiamente a la extinción de un derecho deducida de las consecuencias objetivas del comportamiento del titular de ese derecho, manifiestamente incompatible con el ejercicio mismo de dicho derecho o prerrogativa, con independencia de cualquier culpa, ajeno a la existencia misma de una caducidad o de cualquier otra causa de su extinción prevista por la ley o de una expresión de la voluntad. Con todo, un presupuesto fundamental para la aplicación de la renuncia tácita es que el derecho afectado con la mácula de la extinción sea de libre disposición de su titular (Englebert, Boularbah y Van Drooghenbroeck, 2015,pp. 754, 771-772).

De contera, como ha sido expuesto en derecho francés, el término de prescripción o la prescripción extintiva o adquisitiva tienen un fin eminentemente probatorio: aquel de demostrar la extinción de un derecho, y en el segundo caso, de forma correlativa, la adquisición de uno nuevo. De esta manera, el paso del tiempo se concibe, en sí mismo, como un hecho y como medio de convicción sobre la existencia de ese mismo hecho. Así, la prescripción extintiva es la prueba de la extinción de un derecho por el paso del tiempo, mientras que la prescripción adquisitiva constituye la prueba de una transferencia de propiedad por el paso del tiempo. El término de prescripción es, entonces, una cuestión de interés privado: las partes pueden disponer de él, tal como sucede frente a la posibilidad de demandar en justicia y el contrato de transacción. Esto les permite a las partes renunciar a una prescripción siempre y cuando el tiempo necesario haya efectivamente transcurrido, al tratarse de un acto de disposición de un derecho subjetivo (Rouvière, 2009, p. 7-11).

Así, de acuerdo con la doctrina francesa: "Ese aspecto de interés privado de la prescripción explica que el juez no pueda declararla de oficio: interesa a las partes defender sus propios intereses porque es sobre ellas sobre quienes pesa la carga de la prueba". Es la parte interesada quien tiene que invocarla, como parte de sus medios de defensa procesal. Por eso mismo, el término de prescripción puede ser objeto de interrupción o de suspensión. La interrupción misma de dicho lapso implicaría el hecho de haber desvirtuado la prueba del paso del tiempo. A guisa de ejemplo, téngase que la sola presentación de la demanda demuestra que al acreedor no se le ha pagado y que por eso, el término de prescripción debe recomenzar a contarse de cero. Entre otras cosas, ello hace que no sea posible la repetición del pago de una deuda prescrita, porque ello 
entrañaría una confesión sobre el hecho de que el pago no habría sido hecho. De la misma manera, si el pago ya ha sido hecho, y el deudor paga una segunda vez, la prescripción pierde relevancia porque se estaría, entonces, en el caso de la repetición del pago de lo no debido (Rouvière, 2009, p. 11).

En suma, la prescripción es una excepción de interés privado que permite oponerse a una pretensión de pago que emana de un acreedor, que no es puramente procesal, en la medida en que también permite adquirir un derecho y liberarse de una deuda. Todo, a pesar de que su efecto liberador es el de suprimir simplemente el derecho a perseguir el cobro forzado ante los tribunales y no el hecho de la deuda misma (Van Ommeslaghe, Rechtsverwerking en afstand van recht, 1979, pp. 753-754).

Hechas las anteriores precisiones, para efectos de este estudio, resulta pertinente abordar enseguida el régimen jurídico de los términos de caducidad en el derecho belga, apoyándonos, igualmente, en algunos desarrollos propios evidenciados en el derecho francés. Para tal fin, trataremos, en primer lugar, los efectos jurídicos aunados a la expiración de un término de caducidad, para luego, en segundo lugar, ver su capacidad de ser interrumpidos o suspendidos, y en tercer lugar, apreciar las facultades reconocidas al juez y a las partes en relación con dicha clase de términos. Se comenzará, entonces, por estudiar los efectos jurídicos aunados a la expiración de un término sancionado con caducidad.

\section{EL RÉ GIMEN DE LOS DÉLAISPRÉFIX, DE FORCLUSIONO SANCIONADOS CON CADUCIDAD EN EL DERECHO PRIVADO BELGA}

El efecto más importante de los términos sancionados con caducidad es la desaparición total del derecho. Según lo entiende la doctrina, a diferencia de lo que ocurre con la prescripción extintiva, que no afecta la existencia de la deuda sino solamente su exigibilidad, y que permite así que la obligación subsista en tanto obligación natural, los délaispréfiximposibilitan la existencia de derecho o prerrogativa alguna; ni siquiera de una obligación natural. El efecto de la caducidad es, entonces, automático, pues opera por el solo agotamiento del término sancionado con caducidad ${ }^{3}$. No obstante, si bien la caducidad origina una situación jurídica irrevocable, la jurisprudencia belga permite, en ciertos

\footnotetext{
3 No obstante, un sector de la doctrina flamenca reconoce que el hecho que un deudor siga creyendo, por razones morales o de consciencia, que tiene una obligación a pesar de la caducidad del derecho del acreedor y confirma por hechos positivos tal creencia, éste sería obligado por una (nueva) obligación natural (Cornelis, 2000,917).
} 
casos, que el beneficiario con el agotamiento del término de caducidad pueda renunciar válidamente a éste, siempre y cuando dicho término no interese al orden público (Noël, 2010, pp. 153-154).

En segundo lugar, el irrespeto de un término de caducidad es una causal de inadmisibilidad del acto o de la acción intentado después de haber transcurrido dicho lapso, en tanto excepción perentoria (fin de nonrecevoir) que da al traste con la pretensión sin que se haga necesario examinar el fondo de la misma (Van Drooghenbroeck, 2016, pp. 209$210)^{4}$. En ese sentido, en un sistema de acciones como el del derecho belga, cuando un término de caducidad es impuesto como requisito para la introducción de una acción y que esa acción es intentada después de la expiración del tiempo previsto para ello, el demandado puede oponerse a ella arguyendo, como excepción previa perentoria, “(...) que el juez no tiene poder alguno para conocer de la demanda por ausencia del derecho de acción". La acción es, entonces, inadmisible, porque el derecho de acción ha dejado de existir (Van Drooghenbroeck, 2016, p. 154).

Por último, la caducidad no permite ejercer el derecho o la prerrogativa objeto de la sanción por vía de excepción. Ello implica que, después de acaecido el término de caducidad, no le es dable al titular del derecho prevalerse de él mediante tal medio de defensa. Así, la caducidad no se inscribe dentro del campo de aplicación de la máxima "Quaetemporalia ad agendum, perpetua sunt ad excipiendum" (Van Drooghenbroeck, 2016, p. 155) ("Las acciones son temporales; las prescripciones son perpetuas").

En el derecho francés, por su parte, los términos sancionados con caducidad se han caracterizado por ser lapsos proporcionalmente cortos. De acuerdo con un estudio relativamente reciente sobre el estado de la cuestión en Francia, la mayoría de tales términos tienen una duración comprendida entre 15 días y 2 años. Tales lapsos, en comparación con los términos de prescripción del llamado derecho común, -ahora recortados a cinco años en la última reforma al artículo 2224 y demás normas pertinentes del Código Civil francés- resultan bastante inferiores. No obstante, el término de caducidad, en varios eventos, ha sido establecido por el Legislador en consideración al objeto del derecho que la caducidad impactará negativamente. En el caso de la responsabilidad

4 Como un excepción de fondo, el medio de fin de non-recevoir entraña el fracaso definitivo de la demanda; con todo, al invocarla, el demandado no busca abordar aún el fondo de la pretensión: éste busca a hacer que la demanda se declare inadmisible, sin examen alguno de la cuestión de fondo, por ausencia del derecho de acción. Según la doctrina, se está, en estos eventos, delante una ilustración de la diferencia nítida entre la acción y la demanda. Es lo que sucede cuando el demandado opone al actor la ausencia de interés o de calidad para obrar, la existencia de cosa juzgada, el desconocimiento de un término de caducidad o el agotamiento de un término de prescripción. 
decenal del constructor de una obra civil, el término de caducidad de diez años debe ser apreciado en la medida misma del propósito de preservar indemne al dueño de la obra de cualquier mal funcionamiento o mala organización de la construcción inmobiliaria, teniendo en cuenta la duración de la vida misma esperada de tales bienes (Jeuland y Charbonneau, 2010,pp. 180-181).

Ahora bien, ¿qué sucede con la posibilidad de suspender o de interrumpir los términos de caducidad? Tradicionalmente, en derecho belga se ha dicho que las reglas que gobiernan la interrupción y la suspensión de la prescripción en el Código Civil no se aplican a los llamados délaispréfix, ya que son términos perentorios. En consecuencia, el término de caducidad es un término que, desde que comienza a correr, no cesa su curso sino por la llegada del día de su agotamiento o por la ocurrencia de un evento particular previsto expresamente por el Legislador.

Con todo, se ha aceptado que pueden existir circunstancias excepcionales que pueden permitir la prórroga del término de caducidad. Entre las posibilidades excepcionales que existen para los jueces de prorrogar el término de caducidad está el de la fuerza mayor. La jurisprudencia y la doctrina reconocen que si bien, en principio, el curso de los términos de caducidad no puede ser suspendido ni interrumpido, el juez tiene la facultad de prorrogar dichos términos por el tiempo que sea necesario para el ejercicio de un derecho o para el perfeccionamiento de una finalidad, cuando un evento de fuerza mayor haya impedido al titular del derecho de actuar dentro del término legal. Esta posibilidad tendría fundamento en el adagio "Contra non valentemagere non curritpraescriptio". Para que el beneficiario del derecho o quien tiene la carga de cumplir con la formalidad legalmente prescrita dentro del término de caducidad pueda beneficiarse de su prórroga por fuerza mayor, debe demostrar que un evento imprevisible, irresistible e independiente de su voluntad le impidió respetar cabalmente dicho término. Contrariamente, si en el caso de autos aparece que el titular del derecho ha sido negligente en cumplir con su carga, éste no podrá prevalerse de la fuerza mayor para demandar su prórroga (Jeuland y Charbonneau, 2010, p. 160).

Los efectos de dicha prórroga del término de caducidad no pueden ser, de ninguna manera, confundidos con la suspensión del curso de su agotamiento. Cuando la fuerza mayor impide al interesado actuar en justicia dentro del término establecido so pena de sanción, el término no se prolonga durante toda la duración de la causa de imposibilidad de acción, ni lo suspende. Simplemente, significa que el término de 46 
caducidad se ataja por el término necesario para permitir al interesado presentar su demanda de forma oportuna. En consecuencia, una vez que la fuerza mayor desaparece, el beneficiario de la prórroga tiene la carga procesal de actuar. Sin embargo, los jueces tienen un cierto margen de apreciación en lo concerniente a la duración de la prolongación, que deberá ser fijada en función de las circunstancias de cada caso (Jeuland y Charbonneau, 2010, pp. 161-162).

En cuanto a la manera de computar los términos de caducidad, la doctrina belga y una parte de la jurisprudencia de la Corte de Casación en la sala de habla francesa (Corte de Casación de Bélgica, 1989), sostienen que a tales términos deben aplicársele las reglas para el cómputo de términos establecidos en el Código Judicial. Lo anterior, a pesar de una tesis contraria-sostenida por parte de la doctrina y en un fallo de la sala de habla holandesa de la Corte de Casación-, que impediría que tales términos fueran objeto de prolongación en razón a que el día del agotamiento del término acaeciera en un día inhábil ${ }^{5}$. Esto, debido al carácter sancionador de la caducidad. No obstante, la perentoriedad misma de los términos de caducidad y su drástico carácter extintivo del derecho y de su exigibilidad en sede judicial, a juicio de un sector de la doctrina y una parte de la jurisprudencia civil, debe ser interpretada, por el contrario, como un término cuyo cómputo ha de gozar de las máximas prerrogativas procesales; entre ellas, de la aplicación de las reglas de los artículos 48 y ss. del Código Judicial (Noël, 2010, pp. 166-167).

Por contera, en el derecho francés el término de caducidad:

"Es un término puro, el paso de una cierta cantidad de tiempo en un intervalo en principio netamente determinado: la norma escrita que lo ha instituido precisa su punto de partida y el término no puede ser ni suspendido ni interrumpido. La existencia de soluciones que atenuarían el rigor del paso del tiempo no contraría esa naturaleza particular del término de caducidad siempre y cuando ello no altere el término en sí mismo, no así su punto de partida o sus consecuencias. La especificidad del término de caducidad no resulta, sin embargo, de su naturaleza aritmética, sino más de su finalidad, aquella de dar claridad a una relación jurídica en un lapso restringido, de constreñir a quien está sujeto a la

5 De acuerdo con el inciso $2^{\circ}$ del artículo 53 del Código Judicial de Bélgica, si el día de agotamiento de un término judicial acaece un sábado, un domingo o un día feriado, éste puede ser pospuesto al día hábil más próximo (Englebert, Boularbah y Van Drooghenbroeck, 2015, 53). 
sanción a tomar posición" (Jeuland y Charbonneau, 2010, p. 188).

Dicho esto, resulta importante resaltar que la justificación del término de caducidad estriba en la necesidad de estabilización de una relación jurídica. Entendida de esta manera, la caducidad no persigue únicamente ser una sanción sino de funcionar, al tiempo, como una conminación y una sanción al titular del derecho afectado por los efectos de dicha figura. La conminación es la caducidad misma, es decir, el hecho de privar al titular del beneficio del derecho o de la acción judicial en comento. Esa amenaza tendería a constreñir a dicho titular a asumir una posición dentro de un lapso preestablecido, y en suma, a imponerle la clarificación del derecho incierto del que es titular o la de, eventualmente, llegar a purgar una situación irregular que afecta dicha relación jurídica (Jeuland y Charbonneau, 2010, p. 188).

Los efectos de la caducidad, en derecho francés, pueden, entonces, variar. Cuando no se ejerce el derecho o se realiza la formalidad prescrita por la ley dentro del término de caducidad, la relación jurídica objeto del término será estabilizada de forma definitiva. El efecto de la caducidad, en este caso, será bien el de la purga de las irregularidades que afectan tal situación, o bien el de extender la continuidad de la situación jurídica que existía hasta entonces. Vista de esa forma, la caducidad no tiene exclusivamente una finalidad extintiva, destructiva de la situación jurídica. Ejemplos de lo anterior son los existentes en materia de propiedad intelectual, en donde el agotamiento del lapso impide que una marca posterior registrada cuyo uso fue tolerado por más de cinco años no pueda ser atacada mediante una acción de prohibición de su reproducción fraudulenta (artículo L-716-5 del Código de propiedad intelectual). El efecto más común de la sanción de forclusion, es el de la liberación del deudor mediante la desaparición de una obligación que, hasta antes de acaecido el lapso, se encontraba en estado de latencia: es aquí donde se sienten particularmente sus consecuencias punitivas, en tanto el titular del derecho pierde su derecho, pierde la oportunidad de oponerse a una acción, de que un contrato sea renovado o que se extinga una acreencia (Jeuland y Charbonneau, 2010, pp. 189-190).

Finalmente, en lo concerniente a las facultades del juez y de las partes, enseña la doctrina belga en comento que para determinar las facultades del juez y de las partes respecto de un término de caducidad, hay que examinar, caso por caso, si la disposición legal que lo establece es de orden público. Es decir, si dicha disposición “(...) tiene que ver con los intereses esenciales del Estado o de la colectividad o (...) fija, en el 48 
derecho privado, las bases jurídicas sobre las que reposa el orden económico o moral de la sociedad". Lo anterior, de acuerdo con la clásica enseñanza de la Corte de Casación de Bélgica, establecida mediante Sentencia de 12 de diciembre de 1929. Ha sido la jurisprudencia la que ha establecido el carácter de orden público de ciertos términos de caducidad: por ejemplo, es el caso de la responsabilidad decenal de arquitectos, empresarios y dueños de obra del artículo 1792 del Código Civil. Mientras tanto, los términos previstos por los artículos 18 y 28 de la Ley sobre los arrendamientos comerciales (Ley de 30 de abril de 1951), si bien están sancionados de caducidad, no revisten tal carácter de orden público (Noël, 2010, pp. 167-168).

Así, el poder del juez le permite declarar de oficio la expiración de un término de caducidad a condición que dicho término interese al orden público. En cuanto a las partes, se ha dicho que éstas pueden oponer la expiración de un término de caducidad en cualquier estadio del proceso; incluso en apelación. Sin embargo, el medio de defensa de la caducidad no puede ser invocado por primera vez al interponer recurso de casación ante la Corte de Casación, salvo si el orden público se encuentra en entre dicho. La misma regla se aplica cuando se profiera sentencia en ausencia del demandado, de conformidad con el artículo 806 del Código Judicial. ${ }^{6}$ Todo lo anterior, por supuesto, teniendo en cuenta el respeto de la lealtad procesal, ya que una de las partes no podría censurar en casación una decisión procedimental proferida de forma consonante con sus alegaciones durante ambas instancias, aun cuando ésta tuviera fundamento en el orden público (Corte de Casación de Bélgica, 2012).

El hecho de que el término sancionado con caducidad no sea de orden público le permite al titular del derecho o a quien tiene la carga de perfeccionar una determinada formalidad de renunciar a éste. Inversamente, éste no podría renunciar si el orden público se encuentra comprometido por el cumplimiento del mismo. En Bélgica, la Corte de Casación tuvo lo oportunidad de pronunciarse sobre el particular, en Sentencia de 10 de febrero de 2005(Noël, 2010, 169). Allí, el alto Tribunal dictaminó que el término de un año para demandar las controversias contractuales con el Estado federal o las regiones, contado a partir de la recepción provisional completa de la totalidad de los trabajos o de los suministros, establecido en el artículo $18 \S 2$ del Decreto ministerial de 10 de agosto de 1977, sancionado con caducidad, no era

6 De acuerdo con dicha disposición, reformada por la llamada "Loipot-pourri I", en la sentencia dictada en ausencia del demandado el juez declarará la prosperidad de las demandas o de los medios de defensa de la parte compareciente, salvo en la medida en que el procedimiento, dichas demandas o medios de defensa sean contrarios al orden público. 
un término de orden público ${ }^{7}$. Por tanto, la Corte de Casación belga consideró que, al igual que ocurre con la prescripción, en los artículos 2220 y 2221 del Código Civil, dicho término de caducidad podía ser objeto de renuncia, tácita o expresa, incluso después de agotado el mencionado lapso. Lo anterior, en palabras de dicho alto Tribunal, porque, se explica:

"La introducción de una acción en justicia en materia de contratación estatal no ha sido prevista sino para asegurar la salvaguarda de los intereses del Estado y de las regiones que hoy lo suceden sus derechos en sus relaciones contractuales [en virtud de las leyes de transferencia de competencias federales a las regiones valona y flamenca en materia de contratación pública]. Esa disposición no concierne, en manera alguna, al orden público"(Corte de Casación de Bélgica, 2005).

\section{LAS SANCIONES DE LOS TÉRMINOS PARA ACTUAR A N T E L A J U R I S D I C C I Ó N C O N T E N C I O S O - ADMINISTRATIVA EN EL DERECHO ADMINISTRATIVO BELGA}

En derecho belga, la mayoría de los términos para actuar ante la jurisdicción de lo contencioso-administrativo -en simple nulidad, en

\footnotetext{
7 Sea ésta la oportunidad para precisar que en Bélgica, en principio, el Consejo de Estado únicamente tiene competencia para conocer del control de la legalidad objetiva de los actos administrativos unilaterales que profiera la administración pública. Ello, de acuerdo con el artículo 14 § 1 y $\S 3$ de las Leyes coordinadas sobre el Consejo de Estado (de 12 de enero de 1973). Sin embargo, el Legislador puede atribuir a la jurisdicción contencioso-administrativa (formada casi exclusivamente por el Consejo de Estado y por otros órganos especiales) la competencia para conocer de los efectos económicos, del restablecimiento del derecho o de la reparación de un daño cualquiera causado por los mismos (effetscivils). Así que cuando un derecho subjetivo está en juego frente a un acto de la Administración que se estima contrario a las normas superiores en que debe fundarse, sea éste unilateral o contractual, el litigio sobre los efectos económicos del acto ilegal es en principio competencia exclusiva de la justicia ordinaria, lo que conlleva, necesariamente, a una dualidad de jurisdicciones. Ahora, según los artículos 144, 160 y 159 de la Constitución belga, si lo que se quiere es inaplicar un acto administrativo ilegal, tanto el Consejo de Estado como la jurisdicción ordinaria lo pueden hacer, sean actos reglamentarios o de contenido particular, y además, ésta última jurisdicción tendría competencia para pronunciarse sobre la responsabilidad civil que ello llegue a acarrear para la Administración. Con todo, el artículo 11 bis de las Leyes coordinadas sobre el Consejo de Estado permite hoy en día que la reparación de los daños causados al particular cuya situación jurídica concreta se afectó con un acto administrativo declarado ilegal sea demandada ante el Consejo de Estado. Ello permite que los "effetscivils" de las decisiones administrativas declaradas ilegales no tengan que ser reclamados ante otra jurisdicción distinta. Dicho restablecimiento del derecho puede solicitarse dentro de los 60 días siguientes al fallo que constate la ilegalidad del acto demandado, y precluye toda posibilidad para reclamar la responsabilidad civil causada por la ilegalidad del acto ante la jurisdicción ordinaria (Renders, 2017, 19, 22 y 1165). En cuanto a la responsabilidad del Estado, en virtud del artículo 11 de las Leyes coordinadas sobre el Consejo de Estado permite a dicha Corporación estatuir en equidad sobre las demandas de responsabilidad del Estado en las que el actor no pudiera obtener satisfacción si las demandara ante la jurisdicción ordinaria, como en efecto puede hacerlo, por los causes de la responsabilidad contractual o de la responsabilidad aquiliana del derecho común. En otras palabras, "El Consejo de Estado será competente para conocer del contencioso de la indemnidad [del artículo 11 in fine] en la hipótesis en la que el actor no pueda demandar útilmente ante los tribunales por ausencia de un derecho a la reparación" (Lewalle y Donnay, 2008, 506507).
} 
nulidad con el consecutivo restablecimiento del derecho y en responsabilidad del Estado por daño excepcional- están sujetos a la prescripción extintiva y no se encuentran sancionados con caducidad. Así lo dispone el inciso $2^{\circ}$ del artículo 19 de las Leyes coordinadas sobre el Consejo de Estado cuando habla de "délais de prescription" (Renders, 2017, 1168-1169). Mientras tanto, en materia de controversias contractuales, en lo tocante a los actos pre-contractuales, los términos han sido sancionados por el legislador con la caducidad. De tal manera, para interponer las simples nulidades y las nulidades con la consecutiva reparación de daños en la contratación pública ("marchéspublics"), el artículo $23 \S 1$ de la Ley de 17 de junio de $2013^{8}$ señala que los recursos en comento deben ser introducidos ante el Consejo de Estado o ante la jurisdicción ordinaria -si no se trata de un poder público de adjudicación de aquellos definidos por el artículo $14 \S 1$ de las Leyes coordinadas sobre el Consejo de Estado-, dentro de los términos establecidos para cada tipo de reclamación -60 y 15 días respectivamente-, so pena de inadmisibilidad de la demanda ("à peine d'irrecevabilité").

Sin embargo, como particularidad especial, la jurisprudencia del Consejo de Estadobelga ha establecido que la sanción por incumplimiento del término de prescripción de tales acciones es la inadmisibilidad misma del libelo -irrecevabilité-, controlada de oficio por el juez, con efectos automáticos y de pleno derecho. Al decir de la doctrina, la instauración del contencioso de anulación de los actos administrativos constituye, al tiempo, una importante protección por los derechos de los ciudadanos y una amenaza misma a la eficacia de las actuaciones administrativas. Así que la tensión entre el principio de legalidad-que exige que toda situación contraria a derecho pueda ser retirada del ordenamiento jurídico sin término alguno- y el principio de seguridad jurídica -que ha de impedir que la regularidad de las actuaciones administrativas pueda ser en todo tiempo contestada-, debe ser resuelta mediante una decisión fundamentalmente política. Salvo algunas excepciones -v. gr. la excepción de ilegalidad del artículo 159 de la Constitución belga, o el ejercicio del control contable de la Corte de Cuentas del artículo 180 in fine, donde no hay ningún término establecido para actuar-, el Consejo de Estado ha sido inflexible en cuanto al respecto de los términos de caducidad de las acciones judiciales de su competencia (Leroy, 2011, pp. 485-486).

No habrá que olvidar que las reglas relativas a los términos de interposición de los recursos ante la Sección Contencioso- 
Administrativa del Consejo de Estado de Bélgica son de orden público," “...) de manera tal que incumbe al Consejo de Estado, en caso de necesidad, el resolver de oficio la inadmisibilidad de la demanda por causa de extemporaneidad" (Renders, Bombois, Gors, Thiebaut y Vansnick, 2010, p. 238).

Por vía jurisprudencial, en Bélgica se ha querido entonces respetar la voluntad de preservación de la seguridad jurídica querida por los creadores de las Leyes coordinadas sobre el Consejo de Estado y del reglamento de procedimiento contencioso-administrativo establecido en el Decreto del Regente de 23 de agosto de 1948. Al decir de la doctrina: "esa preocupación de no poner en peligro la seguridad jurídica impone limitar estrictamente el período durante el cual un acto administrativo puede ser objeto de un recurso en anulación" (Leroy, 2011, p. 486). De otro lado, ha quedado también descartada la posibilidad de que el agotamiento del término de introducción de la respectivamente demanda sin el cumplimiento de dicha carga procesal sea esgrimido como excepción perentoria de prescripción por la parte demandada. Así, el recurso en anulación fundado en el artículo $14 \S \S 1$ y 3 de las Leyes coordinadas sobre el Consejo de Estado -que equivale a la nulidad simple y a la nulidad y restablecimiento del derecho en Colombia- está sujeto a un término de 60 días, fijado por el inciso $3^{\circ}$ del artículo $4^{\circ}$ del Decreto del Regente de 23 de agosto de 1948, que determina el procedimiento ante la Sección Contencioso-Administrativa del Consejo de Estado, a cuya expiración se entiende la imposibilidad de invocar, por vía de demanda, la ilegalidad del acto administrativo atacado, tratándose de un acto de contenido particular. Es decir, el Consejo de Estado no puede pronunciarse sobre la legalidad de una decisión administrativa cuando esa decisión se ha vuelto definitiva -esto es, no atacada en anulación dentro del término legal establecido para ello (Consejo de Estado de Bélgica, 2001)(Consejo de Estado de Bélgica, 2010)(Consejo de Estado de Bélgica, 2016)(Consejo de Estado de Bélgica, 2016)-.

Lo mismo sucede con la demanda de reparación por daño excepcional contemplada en el artículo 11 de las Leyes coordinadas sobre el Consejo de Estado. Dicha competencia del Consejo de Estado belga resulta sobre aquellos perjuicios particulares que resultan de limitaciones legítimas al ejercicio de un derecho, notablemente cuando la autoridad administrativa las impone respecto del ejercicio del derecho de propiedad mediante servidumbres de utilidad pública que no son objeto de compensación alguna, o que consisten en lesiones de un interés particular que no tienen origen en la culpa de la Administración (Lewalle y Donnay, 2008, p. 510). En esos casos hay que hacer una petición escrita 52 
previa a la Administración misma, solicitando la reparación pecuniaria del perjuicio sufrido de parte de la autoridad administrativa a la que pueda serle imputable o la expedición del acto administrativo en el que se rechaza total o parcialmente la petición de resarcimiento. Es posible, asimismo, que la Administración sea simplemente negligente de decidir sobre el particular. Para ello, existe un plazo de 60 días a partir de la notificación del rechazo para presentar la respectiva demanda ante el Consejo de Estado. Sin embargo, si al cabo del término de reflexión de que dispone la Administración no se ha producido decisión alguna sobre la petición de reparación -también de 60 días-, el demandante dispone de 3 años a contar del día de introducción de dicha petición para acudir ante el Consejo de Estado (artículo 11, inciso $2^{\circ}$, in fine, y artículo $4^{\circ}$ inciso $4^{\circ}$ del Decreto del Regente de 23 de agosto de 1948) (Lewalle y Donnay, 2008, 516) (Leroy, 2011,pp. 894-895).

En el caso de los términos para solicitar la suspensión provisional ordinaria o la suspensión de extrema urgencia ( "référéadministratif") de la ejecución de un acto administrativo", los términos varían. En el primer evento, la solicitud puede ser presentada en todo momento, antes de introducir el recurso en anulación o al mismo tiempo en que se introduce la demanda, o incluso después de dicho momento, hasta antes de que el agente del Ministerio Público ("auditeur") radique en Secretaría su informe, según el artículo $17 \S 1$ inciso $3^{\circ}$ de las Leyes coordinadas sobre el Consejo de Estado. Tratándose de una suspensión de extrema urgencia, por el contrario, obliga al actor a presentar la solicitud con toda la diligencia que requiere el recurrir a dicho tipo de procedimiento judicial. Así, señala la doctrina que:

"El Consejo de Estado estima que la diligencia con la que la parte actora debe presentar su solicitud se aprecia desde el momento en que ésta ha conocido la decisión administrativa cuya notificación, en razón de las circunstancias del caso concreto puede, según el caso, intervenir mucho después (Renders, Droit administratif général, 2015,pp. 527-528).

Asimismo, el Consejo de Estado puede adoptar cualquier otra medida provisional que sea necesaria para salvaguardar los intereses de las partes o de las personas que tienen interés en la resolución del litigio, lo cual puede ser pedido de forma complementaria a la demanda en anulación (artículo $17 \S 1$ inciso $1^{\circ}$ de las Leyes coordinadas sobre el Consejo de Estado).

9 Lo que equivale en derecho administrativo colombiano a una solicitud de medidas cautelares, entre las que se encuentran, dentro de un amplio espectro de medidas disponibles, la suspensión provisional de los efectos de los actos administrativos demandados, en los artículos 229 y ss. del CPACA. 
Por lo demás, la doctrina y la jurisprudencia del Consejo de Estado de Bélgica han reconocido la existencia de un fenómeno de interrupción del término de caducidad para demandar en anulación actos administrativos. En principio, en derecho belga, la interposición de recursos en vía gubernativa carece de efecto de interrupción en lo que concierne a los términos de caducidad para las demandas ante el Consejo de Estado. La fórmula fue sintetizada por el alto Tribunal en los siguientes términos, según se trate de un recurso expresamente regulado por la ley o no:

\begin{abstract}
"[P]ara decidir si la demanda de anulación ha sido presentada o no tardíamente, se impone calificar los actos por los cuales, antes de acudir ante el Consejo de Estado, el demandante manifestó su oposición a las decisiones atacadas y, más especialmente, determinar si el interesado ha ejercido un recurso organizado o un recurso de gracia; (...) en el primer caso, el término del recurso ante el Consejo de Estado se suspende o se interrumpe hasta el momento en que se decida sobre el recurso organizado presentado previamente, mientras que, en el segundo caso (...), el recurso llamado de gracia carece de efecto suspensivo o de interrupción alguno" (Consejo de Estado de Bélgica, 2005) (Consejo de Estado de Bélgica, 2006).
\end{abstract}

Con todo, existen matices a dicho principio. Se trata de aquellos casos en los que la vía gubernativa no ha sido expresamente prevista por el Legislador, en tanto que ésta no ostenta reglas de formalidades y de términos para su interposición (recoursinorganisé), y dicho recurso ha sido introducido ante la autoridad que ejerce el control de tutela. Si el recurso en cuestión es formulado dentro de los plazos útiles señalados por la jurisprudencia, la introducción del recurso que agotaría la vía gubernativa no expresamente regulado por el Legislador interrumpe el término de caducidad para pedir la nulidad del acto demandado ante el Consejo de Estado. En otras palabras:

"La introducción de una reclamación ante la autoridad que ejerce el control de tutela, cuando ésta exista, interrumpe el término del recurso en anulación, bajo la condición que dicha reclamación sea ella misma presentada dentro del término del recurso en anulación y, entiéndase bien, dentro del término durante el cual la autoridad que ejerce el control de tutela puede todavía anular el acto atacado. Un nuevo plazo de sesenta días comienza a correr desde el día en el que la autoridad que ejerce el control de tutela hace saber al 
reclamante que estima improcedente hacer uso de dicha competencia"

Vale la pena aclarar que, según la doctrina, la jurisprudencia contencioso-administrativa ha dejado claro que ese fenómeno es personal al demandante y de efectos relativos frente a su reclamación (Leroy, 2011, 499) (Lewalle y Donnay, 2008, pp. 862-868) (Renders, Bombois, Gors, Thiebaut y Vansnick, 2010, p. 246).

Por otro lado, cuando la autoridad competente de la vía gubernativa, en ejercicio de un recourshiérarchique (ejercido ante la autoridad que detenta el control jerárquico sobre aquella que profirió el acto) o de un recurso de reconsideración, efectúa un nuevo examen del expediente administrativo - poco importa si añade uno o varios argumentos nuevos o que éstos hayan sido o no invocados por el peticionario, también se interrumpe el término de caducidad para el contencioso objetivo de anulación ${ }^{10}$. Finalmente, el término de caducidad de la acción en nulidad simple también se interrumpe cuando la autoridad competente de un recoursinorganisé (evento en el que puede ser la misma autoridad o aquella que ejerce el control de tutela) decide de suspender la ejecución del acto recurrido y le anuncia al interesado que procederá a un nuevo examen del expediente. Aunque la Administración confirme ulteriormente su decisión, de cualquier modo existe una nueva decisión y, en consecuencia, un nuevo término de caducidad (Goffaux, 2008, p. 208) (Lewalle y Donnay, 2008, p. 869) (Renders, Bombois, Gors, Thiebaut y Vansnick, 2010, p. 246).

Recuérdese que, según el artículo 90 del Decreto del Regente de 23 de agosto de 1948, el término de caducidad del recurso de anulación de los actos administrativos corre igualmente contra los menores de edad, las personas sujetas a interdicción y contra los incapaces. Sin embargo, ello no impide que el Consejo de Estado belga pueda exonerar a tales accionantes de la sanción de caducidad, cuando se demuestre que su representación en estrados no estaba asegurada, en tiempo útil, antes de la expiración de dicho lapso (Renders, Bombois, Gors, Thiebaut y Vansnick, 2010, p. 238). Igualmente, en materia de contratación estatal, según el ordenamiento jurídico vigente, se ha admitido que el término para demandar la anulación de una decisión de no selección, de irregularidad de una oferta o de la no adjudicación de un contrato se

10 “(...) [N] es puramente confirmatoria et da entonces nacimiento a un nuevo término para interponer el recurso, no sólo la decisión que tiene un contenido diferente de la decisión contra la cual el recurso ha sido interpuesto, sino también la decisión que tiene un contenido idéntico, sea que repose sobre una nueva motivación (...), sea que se funde sobre los mismos motivos, pero que ha sido adoptada después de un nuevo examen del expediente"'(Goffaux, 2008, 37). 
interrumpe siempre que el oferente normalmente informado de que ha sido objeto de evicción solicite por escrito, dentro de un plazo razonable de 30 días, en principio, que le sean comunicados los motivos de la decisión de rechazo de su proposición. En ese caso, un nuevo término de 60 días comenzará a correr a partir de la comunicación de los motivos por parte de la entidad adjudicante (Renders, Bombois, Gors, Thiebaut y Vansnick, 2010, p. 247).

Otra posibilidad legal de interrumpir los términos de caducidad de la demanda de nulidad de los actos administrativos es la del inciso $3^{\circ} \mathrm{del}$ artículo 65 de las Leyes coordinadas sobre el Consejo de Estado ${ }^{11}$. En esos eventos, dicha norma sanciona con nulidad la demanda o el memorial presentada en una lengua diferente de aquella impuesta por la legislación sobre el empleo de lenguas. Ésta también interrumpe los términos de prescripción y de procedimiento que no corren durante el trámite de la instancia. Según lo ha entendido el Consejo de Estado belga, esa nulidad, que también declararse oficiosamente, tiene como consecuencia que el término de caducidad vuelva a correr de nuevo ab initio (Renders, Bombois, Gors, Thiebaut y Vansnick, 2010,p. 247).

Sin embargo, al igual que la Corte de Casación de Bélgica, el Consejo de Estado de ese país ha reconocido ciertas hipótesis en que la existencia de una fuerza mayor puede permitir la prolongación del término de caducidad. Para que ello sea así, en general, advierte la doctrina, se ha exigido que la imposibilidad de actuar dentro de dicho término por un evento imprevisible e irresistible sea absoluta (Lewalle y Donnay, 2008, 852). Igualmente, una situación de error invencible podría ser equiparada a dicha fuerza mayor (Consejo de Estado de Bélgica, 1977). Así las cosas, por ejemplo, según la doctrina (Leroy, 2011, p. 504), cuando una huelga generalizada del servicio postal impide al demandante de enviar su reclamación en tiempo útil, se ha aceptado su imposición tardía, siempre y cuando que ésta haya sido enviada una vez la huelga haya concluido (Consejo de Estado de Bélgica, 2002). Igualmente, cuando la perturbación en la prestación normal de los servicios postales ha impedido que el envío que contiene la solicitud de anulación del acto sea estampillada en tiempo útil, aun cuando éste había sido depositado en la correspondiente oficina dentro de los respectivos términos(Consejo de Estado de Bélgica, 2011).

11 Artículo 65, Leyes coordinadas sobre el Consejo de Estado de 12 de enero de 1973: "Son nulas toda demanda y todo memorial dirigidas al Consejo de Estado por una parte sometida a la legislación sobre el empleo de lenguas en materia administrativa en una lengua diferente que aquella cuyo empleo se impone por esa legislación. La nulidad será pronunciada de oficio. Con todo, el acto tachado de nulidad interrumpe los términos de prescripción y de procedimiento; dichos términos no correrán en curso de instancia". 
En otro caso, el Consejo de Estado de Bélgica consideró que los certificados médicos, que no fueron tachados de falso por la Nación, en los que se constata que al momento en que el aviso de que el envío por correo certificado de la decisión atacada fue entregado en la dirección del demandante, éste no se encontraba en condiciones, desde el punto de vista psicológico, de encarar las diligencias administrativas, debían tomarse en consideración con el objeto de justificar una fuerza mayor que retardase el temido efecto perentorio de los términos de caducidad. Además, para el alto Tribunal: "El hecho de que hayan sido obtenidos a una fecha próxima de la introducción de la demanda no permite presumir que se trataría de certificados prefabricados para complacer al fallador ${ }^{\text {"12 }}$. Por último, la jurisprudencia contencioso-administrativa belga, en Sentencia de 25 de febrero de 2003, estimó que la modificación inopinada de los horarios de la oficina postal donde el interesado se presentó a enviar por correo certificado su demanda constituye un caso de fuerza mayor que puede justificar la eventual falta de oportunidad en la presentación de la reclamación en anulación. Así, la demanda radicada en el Consejo de Estado el primer día hábil siguiente a la expiración del término útil para la introducción del recurso debe ser, entonces, admitida (Consejo de Estado de Bélgica, 2003) (Lewalle y Donnay, 2008, p. 653).

En conclusión, en derecho belga, los términos de interposición de las demandas en anulación de los actos administrativos ilegales, y de las demandas de la reparación de los consecuentes daños y perjuicios que se hayan ocasionado con su ejecución son términos de prescripción -salvo en el caso de las controversias contractuales por actos pre-contractuales- Respecto de tales términos, la inadmisibilidad como sanción a la inobservancia del término fue establecida expresamente, cuyos efectos en caso de inobservancia han sido asimilados por la jurisprudencia del Consejo de Estado a los de una caducidad. Asimismo, existen situaciones en las que tales términos son suspendidos, interrumpidos o prorrogados por mandato legal expreso, y otras en que por vía pretoriana se han aceptado no sólo dinámicas propias de la vía gubernativa y de las autoridades competentes para conocer de los recursos administrativos sino también situaciones imprevisibles e irresistibles en la oportunidad de presentación de la respectiva reclamación permitan el acceso a la administración de justicia contencioso-administrativa.

12 En ese caso, el Consejo de Estado belga estimó que “(...) a falta de toda compentencia para apreciar el estado de salud de la demandante entre junio y diciembre de 2002, el Consejo de Estado no puede sino constatar la situación descrita por los medicos" y “(...) que dicha situación es constitutive de un caso de fuerza mayor; que la excepción de falta de oportunidad de la demanda no es de recibo (...)"(Consejo de Estado de Bélgica, 2003) (Lewalle y Donnay, 2008, 653) (Renders, Bombois, Gors, Thiebaut y Vansnick, 2010, 247-248). 


\section{EL ESTADO DE LA CUESTIÓN SOBRE LA CADUCIDAD DE LAS PRETENSIONES O MEDIOS DE CONTROL CONTENCIOSO-ADMINISTRATIVOS EN EL DERECHO COLOMBIANO Y SU PARALELO CON EL DERECHO BELGA}

En Colombia, en el sistema de pretensiones y medios de control introducido por la Ley 1437 de 2011, o Código de Procedimiento Administrativo y de lo Contencioso Administrativo ("CPACA"), conservó los términos para la introducción sancionados con caducidad. De acuerdo con el numeral $2^{\circ}$ del artículo 164 del CPACA, todas las demandas distintas a las de simple nulidad establecidas en el artículo 137 del mismo Código (nulidad electoral, nulidad y restablecimiento del derecho, acción de grupo, repetición, reparación directa y controversias contractuales) deberán ser propuestas en los términos allí establecidos "(...) so pena de que opere la caducidad".

De las palabras empleadas por el Legislador, es posible extraer que la intención es de establecer la caducidad de los términos para presentar las demandas contencioso-administrativas sujetos como una sanción al comportamiento objetivamente culposo del accionante en no ejercer dicho comportamiento a tiempo, que da al traste con su posibilidad de acudir a solicitar alivio judicial efectivo ante la jurisdicción contenciosoadministrativa. Idénticas características a las del derecho belga le ha atribuido la jurisprudencia de la Sección Tercera del Consejo de Estado a la caducidad de los términos para formular en estrados los medios de control del CPACA: (i) Su carácter sancionatorio a la inacción presumida culpable del actor frente a la presentación de la demanda, (ii) su efecto extintivo de la pretensión a invocar una vez agotado el lapso previsto por la ley,(iii) el deber que tiene el juez contencioso-administrativo de declararla de oficio y (iv) su operatividad de pleno derecho sin posibilidad alguna de renunciar a ella o de pactar en contrario. Igualmente, la jurisprudencia contencioso-administrativa ha reconocido que se trata no sólo de una causal de inadmisibilidad de la demanda, cuyo eventual rechazo de plano, en tanto consecuencia natural, le compete al juez cuando resuelva sobre su admisión a trámite, según el numeral $1^{\circ}$ del artículo 169 del CPACA, sino también de una excepción perentoria (mal caracterizada en nuestro derecho como "excepción mixta", susceptible de ser propuesta por el demandado como excepción de mérito o como excepción previa ${ }^{13}$ ).

13 Recuérdese que, de conformidad con el numeral $3^{\circ}$ del artículo 175 del CPACA, todas las excepciones - de mérito, previas y mixtas- deben ser propuestas en la contestación de la demanda. Además, de conformidad con el numeral $6^{\circ} \mathrm{del}$ artículo 180 del mismo Código, las excepciones previas y las excepciones "mixtas" deben ser resueltas en la audiencia inicial. Estas excepciones son las de cosa juzgada, caducidad, transacción, conciliación, prescripción extintiva y falta de legitimación en la causa (que no es una verdadera excepción sino tan sólo un elemento subjetivo de la pretensión que se debe contestar mediante una simple defensa). 
La jurisprudencia de casación civil también ha identificado a la caducidad como un lapso de tiempo cuyo agotamiento tiene efectos perentorios y que es de carácter improrrogable, sin necesidad de actividad alguna del juez ni de la parte contraria. Al decir de la Sala de Casación Civil de la Corte Suprema de Justicia, el fin de la caducidad es preestablecer el tiempo en el cual el derecho puede ser útilmente ejercitado, y por eso, allí se considera tan sólo el hecho objetivo de la falta de ejercicio dentro del término prefijado "(...) prescindiendo de la razón subjetiva, negligencia del titular, y aún la imposibilidad de hecho" (Corte Suprema de Justicia, 1976). Probablemente, por tal jurisprudencia ha hecho carrera en el derecho colombiano la idea según la cual:

"Ilegal resulta cualquier intromisión tendiente a la alteración del mismo, bien sea para prorrogarlo o menguarlo, más, cuando para tal efecto se argumentan conductas subjetivas de la parte en el cumplimiento de una carga, frente a la cual la única consecuencia legal y justa es la deserción de la demanda (Corte Suprema de Justicia, 1997).

Últimamente, la Sala de Casación Laboral de la Corte Suprema de Justicia le atribuyó a la caducidad ser una sanción exclusivamente prevista para las pretensiones contencioso-administrativas, en contraste con las pretensiones propias del proceso laboral, sujeta a prescripción. Esto, sin perjuicio de que deban coexistir en caso de que se discuta el reconocimiento, el pago o la reliquidación de obligaciones pensionales o extralegales, que son de tracto sucesivo, frente a fenómenos de prescripción trienal y de caducidad para empleados públicos y trabajadores oficiales ${ }^{14}$.

\footnotetext{
14 "Otra variación es la que se pone de presente en este asunto, pues mientras que la caducidad está prevista para las acciones que se ventilan ante la jurisdicción contenciosa administrativa, la prescripción es propia de los trámites del proceso ordinario laboral, de modo que, en uno y otro caso, los jueces están en el deber de aplicar con plena observancia de las formas procesales, las disposiciones adjetivas que de acuerdo con la naturaleza del litigio, la jurisdicción y la competencia corresponda. (...).Sin embargo, en caducidad y prescripción también convergen características que se impone destacar. De un lado, ambas figuras fueron establecidas por el legislador con la finalidad de generar seguridad jurídica de manera que las controversias se cierren e impidan la posibilidad de acudir indefinidamente ante la administración de justicia; por ello, una y otra, están sujetas a un límite temporal. De otro, los dos fenómenos resultan inaplicables cuando quiera que se trate de iniciar acciones ordinarias para el reconocimiento de pensión o de su reliquidación por inclusión o exclusión de factores salariales, en tanto esa prestación es periódica o de tracto sucesivo. Por tal razón, el argumento jurídico de la recurrente según el cual «las entidades públicas pueden demandar en cualquier tiempo los actos de reconocimiento de prestaciones periódicas, (...) sin que haya lugar a recuperar las prestaciones reconocidas de buena fe», es totalmente acertado. Frente a esta última característica que les es común, la Sala Laboral de la Corte Suprema de Justicia en procesos en los que se ha discutido el reconocimiento, pago o reliquidación de obligaciones pensionales, legales o extralegales, que por su naturaleza son de tracto sucesivo, frente a los fenómenos de la prescripción trienal prevista en los arts. 488 del CST, 151 del CPT y SS, 41 del D. 3135/1968 y 102 de 1848/1969, y el de la caducidad de las acciones consagrada en el art. 136 del anterior CCA, ha dicho que sus contenidos no riñen entre sí, porque pueden demandarse sin limitación en el tiempo, tanto en la jurisdicción ordinaria laboral como en la contenciosa administrativa"'(Corte Suprema de Justicia, 2016).
} 
Al igual que lo hacen el derecho belga y el derecho francés, la jurisprudencia del Consejo de Estado colombiano le reconoce una función de estabilización de las situaciones jurídicas a los términos de caducidad.

Por ejemplo, en Auto de 5 de marzo de 2015, la Subsección "B" de la Sección Tercera de dicha Corporación así reconoció lo arriba anotado, añadiendo que la caducidad, en tanto castigo al incumplimiento de la carga procesal de impulso del litigio dentro del plazo fijado por la ley, está instituida "Para garantizar la seguridad jurídica de los sujetos procesales $(\ldots)^{15}$ ". En otra providencia, de 27 de marzo de 2014, la Sección Cuarta del Consejo de Estado, además de lo que venimos explicando, estableció que los términos de caducidad, en tanto restricciones al derecho de acceso a la administración de justicia, se habían fijado no sólo por razones de fondo relacionadas con la seguridad jurídica, sino además con la garantía de los derechos subjetivos de los particulares y de la propia administración pública. Unas y ambas razones, a juicio del alto Tribunal, tienen que ver, de un lado, con la existencia de un momento definitivo para la consolidación de las situaciones jurídicas de carácter particular creadas, modificadas o extinguidas mediante actuaciones de la Administración, y de otro lado, con que "(...) los actos administrativos que definen situaciones, reconocen o niegan derechos a los particulares no pueden cuestionarse indefinidamente en sede administrativa o jurisdiccional" (Consejo de Estado, 2014).

Explicaciones parecidas han sido dadas por la Sección Primera de dicha Corporación, frente al recurso de apelación interpuesto por la entidad demandada contra la decisión adoptada en audiencia inicial de declarar no probada la excepción de caducidad de la acción (Consejo de Estado, 2015).

Los términos de la caducidad en el derecho procesal administrativo colombiano han sido instituidos, ciertamente, como parte de las garantías exorbitantes de la Administración, en las que se protege el interés general que anima las actuaciones de las autoridades públicas

15 “7. Para garantizar la seguridad jurídica de los sujetos procesales, el legislador instituyó la figura de la caducidad como una sanción en los eventos en que determinadas acciones judiciales no se ejercen en un término específico. Las partes tienen la carga procesal de impulsar el litigio dentro del plazo fijado por la ley y de no hacerlo en tiempo, perderán la posibilidad de accionar ante la jurisdicción para hacer efectivo su derecho. 8. Es así como el fenómeno procesal de la caducidad opera ipso iure o de pleno derecho, es decir que no admite renuncia, y el juez debe declararla de oficio cuando verifique la conducta inactiva del sujeto procesal llamado a interponer determinada acción judicial. La caducidad ha sido entendida como la extinción de a posibilidad de formular una pretensión por el transcurso del tiempo previamente fijado por la ley en forma objetiva" (El énfasis es nuestro) (Consejo de Estado, 2015). 
mediante diversas figuras. Los poderes exorbitantes en materia de contratación estatal, la responsabilidad fiscal mediante procedimiento administrativo con posibilidad de decretar medidas cautelares aún sin que exista decisión definitiva, la existencia misma de una jurisdicción contencioso-administrativa, entre otros, forman parte de las facultades conferidas por el Legislador a la Administración que la colocan en desigualdad de condiciones frente a los particulares y que la rodean de privilegios justificados en el cabal cumplimiento de los fines del Estado.

Valga la pena señalar que, en Colombia, los términos de caducidad de los medios de control contencioso-administrativos, al estar incluidos en la Parte Segunda del CPACA sobre la organización de la jurisdicción de lo contencioso-administrativo y de sus funciones jurisdiccional y conclusiva, vendrían a tener el carácter de normas procesales. Dicho carácter hace que tales disposiciones sean en su totalidad de orden público y de obligatorio cumplimiento, y que en ningún caso, éstas puedan ser objeto derogación, modificación o sustitución alguna por los funcionarios o por los sujetos procesales, salvo disposición legal expresa en contrario, de conformidad con el inciso $1^{\circ}$ del artículo 13 del Código General del Proceso ${ }^{16}$. Así, como excepción a dicha regla, el propio artículo 119 de dicho Código ha establecido que "Los términos son renunciables total o parcialmente por los interesados en cuyo favor se concedan. La renuncia podrá hacerse verbalmente en audiencia, o por escrito, o en el acto de la notificación personal de la providencia que lo señale" (El énfasis es mío). Dicha norma encuentra justificación en lo establecido por el artículo 15 del Código Civil ${ }^{17}$. Tales normas son de aplicación en esta especialidad jurisdiccional de conformidad con lo establecido por el artículo 307 del CPACA, teniendo en cuenta que, en cuanto regulan los vacíos o las deficiencias de dicho Código en asuntos procedimentales, son compatibles con la naturaleza de los procesos y de las actuaciones que corresponden a la jurisdicción de lo contenciosoadministrativo.

Frente a la posibilidad de suspensión del término de caducidad para la formulación en sede judicial de los medios de control contenciosoadministrativo, bien sabido es que la única posibilidad admitida por el Legislador es la presentación de la solicitud de conciliación extrajudicial, como requisito de procedibilidad, ante los Procuradores Judiciales competentes. Tal figura implica, entonces, que el término de

16 Artículo 13, inciso $1^{\circ}$, Código General del Proceso: “Las normas procesales son de orden público y, por consiguiente, de obligatorio cumplimiento, y en ningún caso podrán ser derogadas, modificadas o sustituidas por los funcionarios o particulares, salvo autorización expresa de la lev”" (El énfasis es mío).

17 Artículo 15, Código Civil: "Podrán renunciarse los derechos conferidos por las leyes, con tal que sólo miren al interés individual del renunciante, y que no esté prohibida la renuncia” (El énfasis es mío). 
caducidad se suspenderá -es decir, que su curso se detendrá momentáneamente y luego será inexorablemente reanudado- desde la presentación de la solicitud hasta cuando acaezca alguno de los eventos de los literales a), b) y c) del artículo $3^{\circ}$ del Decreto 1716 de 2009. Esto es, el logro de un acuerdo conciliatorio, la expedición de constancias de agotamiento del requisito de procedibilidad o el vencimiento de un término de tres meses contados a partir de la presentación de la solicitud. De acuerdo con el parágrafo único de la disposición en comento, "Las partes por mutuo acuerdo podrán prorrogar el término de tres (3) meses consagrado para el trámite conciliatorio extrajudicial, pero en dicho lapso no operará la suspensión del término de caducidad o prescripción" (El énfasis es mío).

Lo mismo sucede con la posibilidad de interrumpir el término de caducidad. La única eventualidad en que ello puede suceder-al igual que con la prescripción, aunque la ley no habla explícitamente de interrupción- es el hecho de haber logrado notificar el auto admisorio o el correspondiente mandamiento de pago al demandado dentro del año siguiente a la notificación de dichas providencias al actor. De conformidad con el inciso $1^{\circ}$ del artículo 94 del Código General del Proceso:

La presentación de la demanda interrumpe el término para la prescripción eimpide que se produzca la caducidad siempre que el auto admisorio de aquella o el mandamiento ejecutivo se notifique al demandado dentro del término de un (1) año contado a partir del día siguiente a la notificación de tales providencias al demandante. Pasado este término, los mencionados efectos solo se producirán con la notificación al demandado (El énfasis es mío).

De otro lado, en Colombia no se ha aplicado la solución propuesta por la jurisprudencia belga frente a la posibilidad de prórroga de los términos de caducidad. La jurisprudencia del Consejo de Estado, al igual que como se hace en derecho francés, del que es heredera la jurisprudencia de casación nacional, ha adoptado la concepción de que la caducidad es un término de contabilización aritmética, que gozaría al menos de la aplicación de las reglas de cómputo establecidas para los términos judiciales propuestas en el artículo 118 del Código General del Proceso -equivalente al Código Judicial belga-, pero que no puede ser objeto de interrupción ni suspensión alguna. Con todo, este alto Tribunal ha previsto hipótesis en las que operaría una atenuación de la imposibilidad 62 
de interrumpir o de suspender el término de caducidad sin tener que interrumpir, ni suspender ni prorrogar dicho lapso por vía de adjudicatio. Así, en lugar de proponer la fuerza mayor como posibilidad de prórrogadel término de caducidad de una pretensión contenciosoadministrativa, la Sección Tercera del Consejo de Estado ha recurrido a la ingeniosa salida de modificar el momento de inicio de cómputo del término. Esto, para permitir que el curso del lapso a agotar, y dentro del que el actor debe actuar so pena de perder su derecho de interponer la correspondiente demanda contencioso-administrativa, sea iniciado desde un momento posterior al hecho que le sirve de causa. Esta, como se tuvo oportunidad de verlo, encuentra eco en el derecho francés -en el que se apoya, al parecer, la Sala de Casación Civil de la Corte Suprema de Justicia colombiana-, donde el carácter concluyente y definitivo del término impide su interrupción, suspensión o prórroga, incluso por motivos de fuerza mayor, salvo disposición legal en contrario.

El fundamento de tal solución ha sido variopinto. En las demandas de reparación directa, en unas ocasiones, se ha argüido la necesidad de distinguir entre las consecuencias materiales del hecho que genera la reclamación contencioso-administrativa; en otras, se han invocado aforismos como los principios pro damato y pro actione. Existen varios ejemplos de lo anterior. Para comenzar, en las demandas de reparación directa, el término de caducidad, de acuerdo con el inciso $1^{\circ}$ del literal i) del numeral $2^{\circ}$ del artículo 164 del CPACA, vence dentro del lapso bienal contado a partir del día siguiente al de la ocurrencia del hecho causante del daño, del momento en que el actor tuvo o debió tener conocimiento del mismo si ello ocurrió en fecha posterior, siempre y cuando éste obre de buena fe. Al respecto, se ha admitido por la jurisprudencia contencioso-administrativa que tal inicio del término sea interpretado de manera generosa en caso de los daños que se agravan con el tiempo, de aquellos que se producen sucesivamente o que son el resultado de hechos sucesivos.

En términos generales, cuando los daños provienen de un suceso instantáneo, en el que coinciden el hecho dañoso y la materialización del daño mismo, el término de caducidad ha de contabilizarse desde el momento mismo en que dicho hecho dañoso se produce. Cuando el daño proviene de un hecho que se va produciendo en forma paulatina, se ha establecido que el término empezará a correr desde el instante en que se agote el hecho que dé origen efectivo al daño y se verifique su cesación. Y cuando se trate de daños continuados, producidos por fenómenos sucesivos y homogéneos, el término de caducidad se computará de manera independiente para cada uno de los daños derivados de esos 
eventos sucesivos, a partir del momento en que se tuvo conocimiento razonable de ellos ${ }^{18}$.

La alusión a los principios pro damatoy pro actione, que al parecer habrían sido traídos del derecho administrativo español, respondieron a la necesidad de permitir, bajo la égida del artículo $136 \mathrm{del}$ anterior CCA, que el juez pudiera computar el plazo de caducidad a partir del momento en el que el demandante habría conocido la existencia del hecho dañoso. Ello, habida cuenta de que sólo a partir de esa fecha podría estimarse razonablemente que éste tiene un interés actual para solicitar alivio judicial efectivo. Asimismo, se buscó, con la aplicación de tales aforismos, aliviar los rigores de las normas que, como los términos de caducidad, consagran plazos extintivos para el ejercicio de las acciones, buscando que éstas sean interpretadas con cautela y bajo un criterio netamente restrictivo ${ }^{19}$.

Tal subregla jurisprudencial fue de socorrida utilización en los casos de responsabilidad del Estado por desaparición forzada, antes de que fueran reglamentados por el artículo $7^{\circ}$ de la Ley 589 de 2000 -que modificó el inciso $2^{\circ}$ del numeral $8^{\circ}$ del artículo 136 del anterior CCA-, y del nuevo inciso $2^{\circ}$ del numeral $2^{\circ}$, literal i) del artículo 144 del $\mathrm{CPACA}^{20}$.

En una variante de esa posición jurisprudencial, el deber de rechazar de plano una demanda por caducidad ha sido interpretado de forma favorable a la parte demandante, con el fin de favorecer el derecho de acceso a la administración de justicia y a la sentencia de fondo misma. Con fines ilustrativos, se pone de presente que la Sección Cuarta del Consejo de Estado ha establecido que, tratándose de la nulidad y restablecimiento del derecho de actos administrativos de carácter tributario, cuando uno de los puntos de la demandasea precisamente controvertir la notificación misma del acto acusado, al juez contenciosoadministrativo le es dable abstenerse de rechazar de plano de la demanda por caducidad. Sin embargo, ello sólo tiene cabida cuando exista una duda razonable acerca del agotamiento de dicho término sin que la demanda haya sido interpuesta de forma oportuna. La justificación de esta tesis recaería sobre el hecho de que una indebida o falta de notificación de los actos enjuiciados, o la existencia de razones serias para desconfiar del acaecimiento de la caducidad, fundamentadas en consideraciones objetivas -en tanto situaciones de hecho sujetas a prueba- y no caprichosas, sería suficientemente plausible para que se

18 Ver, entre otras: Consejo de Estado, 2011; Consejo de Estado, 2014.

19 Ver, entre muchas otras: Consejo de Estado, 1997; Consejo de Estado, 2004; Consejo de Estado, 2000.

20 Ver, entre muchas otras: Consejo de Estado, 2007. 
prefiera admitir la demanda, y para que la caducidad se estudie como excepción "mixta" al momento de proferir sentencia".

Con todo, esa misma Sección del máximo Tribunal de lo Contencioso Administrativo también ha aceptado que situaciones excepcionales constitutivas de fuerza mayor puedan llegar a suspender el término de caducidad. Es el caso, por ejemplo, de lo que ocurre con el cómputo de los términos de caducidad mientras existen paros de la Rama Judicial. El cese forzado y temporal de actividades en la justicia, por parte de sus empleados sindicalizados, implicaría el ejercicio del derecho de huelga en los servicios públicos esenciales, de conformidad con el artículo 125 de la Ley 270 de $1996^{22}$. Para la Sección Cuarta del Consejo de Estado, se trata, en efecto, de una situación de fuerza mayor que debe ser apreciada a la luz de la buena fe y del derecho de acceso a la administración de justicia, teniendo en cuenta el comportamiento diligente de la parte actora en introducir la demanda.

Mediante Auto de 4 de diciembre de 2014, dicha Corporación revocó la providencia de primera instancia del Tribunal ' $a q u o^{\prime}$ en la que se declaraba caduca una demanda contra una sanción administrativa tributaria presentada después del término de caducidad -apenas dos días después de vencido el respectivo lapso-, habiendo mediado un cese forzado e indefinido de actividades en la Rama Judicial, entre octubre y diciembre de 2012, convocado por su sindicato más grande, durante su curso. Tal evento fue definido como "(...) un evento extraordinario que impidió a los usuarios el acceso a los despachos judiciales para presentar demandas, recursos y demás actos procesales necesarios para poner en funcionamiento el aparato judicial". Teniendo en cuenta lo establecido en el artículo 62 del Régimen Político Municipal (Ley $4^{\mathrm{a}}$ de 1913) y en el artículo 121 del anterior Código de Procedimiento Civil -hoy artículo 118 del Código General del Proceso-, el alto Tribunal estimó que durante el período en que estuvieron cerrados todos lo despachos no corrieron términos legales, y que, por tanto, cualquier plazo que estuviera corriendo se había interrumpido y que aquel que hubiera vencido durante la cesación de actividades de la Rama Judicial se extendería al primer día hábil en que se reanudaron las labores. Contrario a la decisión

21 Ver, entre otras: Consejo de Estado, 2000; Consejo de Estado, 2009; Consejo de Estado, 2014.

22 El derecho de huelga en los servicios públicos esenciales, de los que hace parte la administración de justicia, implica el ejercicio de dicha prerrogativa de los trabajadores para buscar la solución de un conflicto colectivo de trabajo dentro de restricciones adecuadas, necesarias y estrictamente proporcionadas, en las que se equilibren sus intereses con los usuarios de servicios “(...) cuya interrupción podría poner en peligro la vida, la seguridad o la salud de la persona en toda o parte de la población ”(Caicedo Pérez, 2015, 94). Por supuesto, la consideración que hace la Sección Cuarta del Consejo de Estado en la providencia en comento implica no puede trasladarse a la diligencia o al cuidado de un justiciable la determinación sobre la ocurrencia de una huelga en la Rama Judicial que imposibilite la radicación oportuna de demandas contenciosoadministrativas y la extensión de aquella en el tiempo. 
recurrida, la Sala de Decisión en comento estimó que la parte actora había actuado de buena fe y que por ello no debía impedírsele el acceso al alivio judicial efectivo, ya que sabía cuándo se vencía el plazo para instaurar la demanda, había determinado quién era el juez competente para conocer de su caso - a pesar de que se equivocó en esa estimación- y que éste procuró de manera diligente presentar la demanda en la respectiva Oficina de Apoyo para que fuera repartida a un juez administrativa, a pesar de que ello no fue posible por el cierre de los despachos judiciales. Por eso, a juicio del máximo Tribunal de lo Contencioso Administrativo, la demanda debía tenerse por presentada en tiempo ${ }^{23}$.

Empero, tal subregla jurisprudencial ha sido de una aplicación más restrictiva en otras Secciones del Consejo de Estado. En efecto, en un Auto de 31 de agosto de 2015, la Sección Primera de dicha Corporación estableció que el cómputo de los términos de caducidad del medio de control de nulidad y restablecimiento del derecho se ha establecido en meses calendario - y no hábiles-, que el término de caducidad empieza a correr el día siguiente de su notificación o comunicación -sea éste un día hábil o inhábil- y que el término de su vencimiento, de ocurrir un día inhábil, será extendido al día hábil siguiente. En ese sentido, el alto Tribunal hizo énfasis en que las reglas del artículo 118 del Código General del Proceso y del artículo 62 de la Ley $4^{\text {a }}$ de 1913 no se aplicaban al momento del inicio del conteo del término, y además, en que como los términos de meses y años finalizan en la misma fecha en que comienza, a éstos no se les aplica las mismas reglas de los términos contados en días y horas, que se entenderán hábiles a menos que se establezca lo contrario. Sólo ante estos términos el carácter hábil o inhábil de los días tiene incidencia en el conteo (Consejo de Estado, 2015).

Pero aquello en que difiere de la providencia proferida por la Sección Cuarta de ese mismo alto Tribunal, es que, en esta oportunidad, la

23 “....) [S] observa que el apoderado del actor creía que el asunto no superaba los 300 salarios mínimos legales vigentes y en ese entendido tenía el total convencimiento de que los competentes para conocer del proceso eran los jueces administrativos y, por esa razón su intención siempre fue interponerla ante esa autoridad. De esa convicción no puede derivarse ninguna mala intención, por el contrario el apoderado del señor Santiago Hernándezactuó de buena fe y de manera diligente, pues estuvo pendiente de que le permitieran el ingreso a la Oficina de Apoyo de los Juzgados Administrativos, de forma tal que pudiera presentar la demanda en tiempo. Si bien es cierto que se cometió un error al calcular el valor equivalente a 300 salarios mínimos legales vigentes para el año 2012 y en ese entendido el apoderado del demandante creyó que la cuantía de la demanda era inferior a ese valor, este error no puede traer como consecuencia la denegación del derecho de acceso a la administración de justicia, puesto que si la situación extraordinaria de paro no hubiera existido la demanda habría sido interpuesta en tiempo ante los juzgados administrativo que, al advertir que no eran competentes, la habrían remitido al Tribunal Administrativo de Cundinamarca. Empero, como se presentó el paro, circunstancia extraordinaria que en los juzgados de Bogotá se extendió hasta el 10 de diciembre de 2012, en el sub lite, en el contexto de los hechos narrados, la demanda debe tenerse presentada en tiempo" (Consejo de Estado, 2014). 
Sección Primera del Consejo de Estado estima que cuando el término de caducidad de una pretensión contencioso-administrativa se prevé por el Legislador en meses, para su cómputo no se tienen en cuenta los días de vacancia judicial, o los que, por cualquier causa el Despacho deba permanecer cerrado. Es lo que ocurre, en la especie, con el paro judicial: esos días de cesación temporal de actividades de la Rama Judicial no suspenden ni interrumpen el término de caducidad, de suerte que si el vencimiento del mismo ocurre en aquellos días, el término se extenderá al día hábil siguiente. De acuerdo con el Auto de 31 de agosto de 2015, que a su vez reitera al parecer una posición propia de esa Sala de Decisión (Consejo de Estado, 2015)(Consejo de Estado, 2011)(Consejo de Estado, 2010), “(...) los días de vacancia judicial, o aquellos en los que el Despacho deba permanecer cerrado, por cualquier causa, como ocurrió con el paro judicial, no suspenden el término de caducidad, de suerte que si el mismo se vence en este tiempo, el medio de control debe interponerse al día hábil siguiente (...)" (Consejo de Estado, 2015) (Consejo de Estado, 2011) (Consejo de Estado, 2010).

\section{A MODO DE CONCLUSIÓN, ALGUNAS REFLEXIONES APOYADAS EN EL DERECHO BELGA PARA ATEMPERAR LA PERENTORIEDAD DE LOS TÉRMINOS DE CADUCIDAD ESTABLECIDOS EN EL CPACA Y LOGRAR SU EVENTUAL APLICACIÓN EN DERECHO ADMINISTRATIVO COLOMBIANO}

En opinión de quien escribe estas líneas, la institución del término de caducidad en el ordenamiento jurídico colombiano cumple exactamente la misma función y comparte las mismas características que las instituciones de la déchéance (hetrechtverval), del vervaltermijny de los délais de forclusionde los derechos belga y francés. Se trata de una figura plenamente diferenciada de la prescripción extintiva de las acciones, que si bien es difícil de definir, tiene sus contornos y efectos jurídicos propios. En ese sentido, al entender la caducidad como una sanción y no como un término cuya función es la de demostrar la pérdida de un derecho (o la correlativa adquisición de uno), es fácil explicarse por qué ésta se cierne de manera perentoria e inexorable sobre quien tiene la carga procesal de presentar una demanda contencioso-administrativa dentro de los plazos establecidos para ello por el artículo 164 del CPACA. También resulta razonable encontrar soluciones que permiten darle aplicación útil a la norma, para materializar el respeto a la seguridad jurídica y a la efectividad misma de los derechos subjetivos. Especialmente, teniendo en cuenta que, en principio, no existe interrupción ni suspensión alguna del término fuera de las causales 
establecidas por el Legislador, y donde las soluciones que se imponen para conciliar las circunstancias del caso concreto con dicha figura-para proteger las garantías procesales fundamentales- van desde la aceptación de la fuerza mayor hasta el cómputo laxo del inicio del término.

Sin embargo, resulta oportuno efectuar algunas precisiones sobre la aplicación de los efectos perentorios de los términos de caducidad en el derecho administrativo colombiano. En primer lugar, es preciso poner de presente que la mayoría de las soluciones a que ha llegado el juez contencioso-administrativo en Colombia no han tenido en cuenta que las nefastas consecuencias del agotamiento de los términos de caducidad, en los casos que se han reseñado hasta ahora, sólo se han pensado respecto de los efectos que ello causa cuando es el administrado y no la Administración quien hace uso de los medios de control contenciosoadministrativos. Esto se hace plausible, de forma notoria, cuando la Administración ha de demandar sus propios actos administrativos de contenido particular, que producirían efectos patrimoniales adversos al erario y contrarios a los fines del Estado. Con la desaparición de la acción de lesividad, instaurada en el numeral $7^{\circ}$ del artículo 136 del anterior CCA, aparejada de un lapso bienal, y con la procedencia excepcional de la simple nulidad contra actos de contenido particular - que le impediría a la entidad pública demandar su propio acto en cualquier tiempo si se desprende de la demanda que se persigue el restablecimiento automático de un derecho (como el pago de una suma fija o periódica)- establecida en el inciso $4^{\circ}$ del artículo 137 del CPACA, la Administración queda hoy sujeta a demandar sus propios actos dentro del lapso cuatrimestral establecido en el literal d), numeral $2^{\circ}$ del artículo 164 del CPACA.

En ese orden de ideas, en principio, la Administración quedaría en igualdad de condiciones frente a los particulares para la presentación de este medio de control de nulidad y restablecimiento del derecho. Esto, teniendo en cuenta que ésta tiene el deber de buscar la reparación del daño causado por el pago de sumas a los administrados que no consintieron en la revocación del acto de carácter particular y concreto que se estima ilegal, o a quienes el acto demandado modificó su situación jurídica particular a causa de medios ilegales o fraudulentos. Ese es el deber de conducta que le ha sido impuesto por los incisos $2^{\circ}$ y $3^{\circ}$ del artículo 97 del $\mathrm{CPACA}^{24}$. De contera, no

24 Artículo 97, incisos $2^{\circ}$ y $3^{\circ}$, CPACA: “(...) Si el titular niega su consentimiento y la autoridad considera que el acto es contrario a la Constitución o a la ley, deberá demandarlo ante la Jurisdicción de lo Contencioso Administrativo. Si la Administración considera que el acto ocurrió por medios ilegales o fraudulentos lo demandará sin acudir al procedimiento previo de conciliación y solicitará al juez su suspensión provisional". 
olvidemos que los términos de caducidad constituyen una prerrogativa exorbitante de la administración pública. Ello, en tanto que ésta goza de la posibilidad de que la caducidad sea declarada de oficio, bien en el control de admisibilidad de la demanda, bien resuelta de plano en la audiencia inicial, y además, de que sea resuelta como excepción de fondo en la sentencia, según el artículo 180 numeral $6^{\circ}$ del CPACA. El Legislador, en aras de proteger el interés general, sometió el acceso a la justicia contencioso-administrativa a una sanción y no a un término de prescripción, con dos finalidades: de un lado, proveer a la seguridad jurídica, y de otro lado, buscando paliar la imposibilidad para la Administración de velar con la misma diligencia que un buen padre de familia por la defensa del interés general cuando éste resulta ser una cuestión litigiosa. De manera que, no cabe duda, cualquier interpretación de las normas sobre caducidad debe también considerar la situación en la que la Administración actúa como demandante, so pena de violar la igualdad de armas contenida en los artículos 13 y 29 de la Constitución Política y el artículo $8^{\circ}$ numeral $1^{\circ}$ de la Convención Americana sobre Derechos Humanos (Ley 16 de 1972).

Dicho esto, cabe preguntarse si allí también si los jueces contenciosoadministrativos están en disposición de aplicar, con el mismo rigor que lo hacen para los particulares, los términos de caducidad de los medios de control contencioso-administrativos en las demandas que en ese sentido presente la administración pública para la salvaguarda del interés general. Perseguir cualquier restablecimiento, reparación o restitución consecuencial o relacionada a la legalidad objetiva de un acto administrativo le impone a la Administración la carga procesal de demandar dentro de los 4 meses siguientes a la notificación o comunicación del acto eventualmente enjuiciado. O si, por el contrario, podría decirse que los jueces contencioso-administrativos han confiado en la efectividad de la acción de repetición o en la plena operatividad del procedimiento disciplinario y del procedimiento de responsabilidad fiscal, sin reparar que muchas veces la administración pública se encuentra desbordada para intentar demandas 1o suficientemente oportunas y bien fundamentadas en contra de los administrados, o en que muchas de esas decisiones administrativas pueden resultar anuladas por violación de las normas superiores en que deben fundarse. En especial, vale la pena poner de presente lo concerniente al ejercicio de la acción de repetición, cuya puesta en marcha no ha tenido el efecto deseado por el Legislador frente a la salvaguardia del erario en los casos en que la responsabilidad personal del agente que causa un daño antijurídico en sentido lato compromete 
aquella del Estado ${ }^{25}$. Ello, aun cuando la Administración contaría con las prerrogativas procesales que confiere el CPACA, y como ocurre en la mayoría de los casos, con el favor del juez contenciosoadministrativo -su juez natural-en la tramitación de las demandas.

Ahora, en segundo lugar, además del problema de la fuerza mayor como atemperación de los efectos perentorios del agotamiento pasivo del término de caducidad, está el asunto de la renuncia al término de caducidad. Dicha posibilidad entrañaría la disposición misma del término de caducidad en tanto asunto de interés exclusivo del renunciante, aun cuando sea de orden público. La consideración hecha por la jurisprudencia contencioso-administrativa sobre que la caducidad no podría ser objeto de renuncia alguna sería, evidentemente, contraria a derecho, según lo vimos en los párrafos precedentes. Dado que los términos de caducidad son también términos, y que a pesar de ser normas de orden público pueden ser también objeto de renuncia total o parcial -por atender a un interés particular-, no existe justificación legal alguna para prohibir, por vía jurisprudencial, la renuncia de los términos de caducidad, so pretexto de que para la entidad pública o para el administrado la renuncia a la caducidad de los términos entrañaría un menoscabo del interés general o de su garantía a los derechos subjetivos que detenta. Es el Legislador mismo el que ha autorizado, de forma excepcional, la renuncia a términos dentro de las actuaciones judiciales aunque éstos sean de orden público, en la que se incluirían sin hesitación alguna los términos de caducidad.

Además, el hecho de que una norma sea de orden público significa, en realidad, que existe una protección jurídica de un interés que concierne a los fundamentos mismos de la paz social y de la vida en comunidad, y que, por tanto, ha de ser el juez quien haga efectiva esa protección de oficio. Dicha protección debe ser, entonces, puesta en marcha por iniciativa del fallador en cualquier momento del proceso, sin necesidad de demostrar perjuicio alguno en cabeza de alguna de las partes ${ }^{26}$. Por

25 Entre las críticas más frecuentes al ejercicio de dicha acción se encuentran: (a) La falta de objetividad de Comité de Conciliación al conceptuar sobre el funcionario responsable actuó con culpa grave o dolo, especialmente si quien es objeto del concepto es un funcionario o directivo de alto nivel o pertenece a distintas tendencias políticas; (b) Un número significativo de demandas de repetición no se tramitan hasta su culminación porque los jefes de las entidades públicas no asignan recursos especialmente destinados a tal fin o por falta de diligencia en la actividad probatoria con relación a las condiciones de validez y eficacia de la acción; (c) La duración promedio de un proceso de repetición es en promedio de 9,8 años, entre la presentación de la demanda y el fallo de segunda instancia (Torres Calderón, 2005, 4 y s.) (Duque Sánchez, 2012, 136-153).

26 En un sistema de acciones como aquel del derecho belga, la existencia de términos sancionados con caducidad para el ejercicio de ciertos actos procesales (délaisd'accéleration)-v. gr. omo la interposición de recursos- implica que el juez ha de protegerlos de oficio. Ello, en oposición a los términos sancionados so pena de nulidad (délaisd'attente), en los que debe ser la parte beneficiada con alegarla quien debe hacerlo in liminelitis y bajo prueba del perjuicio que con su desconocimiento se le causa(Van Drooghenbroeck, 2016, 224 y s.) 
eso, las nociones de interés general y orden público no son nociones equivalentes ni íntimamente ligadas ${ }^{27}$, aunque en varias ocasiones el orden público se instaure como límite a los actos positivos de las personas para la protección del interés general (p. ej., las normas que regulan la nulidad absoluta de un contrato estatal), o aun cuando en tantas otras se protejan mediante leyes de orden público asuntos propios de derechos subjetivos (v. gr., como ocurre en las normas de derecho de familia sobre estado civil, filiación y adopción). Lo anterior, teniendo en cuenta que "(...) el orden público en un Estado social de derecho supone también las condiciones necesarias e imprescindibles para garantizar el goce efectivo de los derechos de todos" (Corte Constitucional, 1994), y que, en esa medida, no es el interés general en tanto fin del Estado con la actuación administrativa lo que se protege mediante los términos de caducidad sino la legalidad y la seguridad jurídica mismas de las situaciones jurídicas particulares.

La importancia de que se acepte la posibilidad de renuncia de los términos de caducidad no sólo por parte de las entidades públicas sino también de los administrados que las demandan resulta radical en materia de gestión de los conflictos judiciales y extrajudiciales de la Administración. Piénsese, por ejemplo, en los casos en que para que un litigio pueda ser objeto de solución final en una conciliación contencioso-administrativa-que es, en el fondo, una transacción a la que se llega con la intervención del conciliador- se deba renunciar, en medio de las concesiones mutuas, al ejercicio de las pretensiones contenciosoadministrativas de cada una de las partes. El asunto es notorio en las conciliaciones judiciales o extrajudiciales que resuelven cuestiones de controversias contractuales. ¿Debe exigírsele al contratista que, para saldar sus cuentas con la entidad pública contratante, renuncie al ejercicio de sus pretensiones contencioso-administrativas, mientras que aquella, sujeta a los vaivenes de los cambios en la titularidad de su dirección y manejo -y a las presiones de los entes de control-, puede terminar de nuevo reclamando por controversias contractuales surgidas de la conciliación porque en principio -por motivos poco claros- le estaría vedado renunciar al ejercicio de tales pretensiones? ¿Qué hay del respeto al mérito ejecutivo y al tránsito a cosa juzgada del acuerdo conciliatorio cuando la Administración, bajo la tesis de que los términos de caducidad de las controversias contractuales son irrenunciables por

27Aunque pareciera que, en la opinión de la Sección Primera del Consejo de Estado, lo correcto fuera lo contrario. Particularmente, cuando se afirma - con base en la jurisprudencia constitucional-, en reciente providencia, que el fundamento de la caducidad "(...) se halla en la necesidad por parte del conglomerado social de obtener seguridad jurídica, para evitar la paralización del tráficojurídico. En esta medida, la caducidad no concede derechos subjetivos, sino que por el contrario apunta a la protección de un interés general "(Elénfasis es mío) (Consejo de Estado, 2015). 
ser de orden público - confundido éste con el interés general-, podría interponer nuevas pretensiones con fundamento en hechos, pretensiones y causas idénticas?

En la actualidad se está, entonces, a la espera de conocer que dicho interrogante haya sido resuelto o que éste será resuelto por la jurisprudencia del Consejo de Estado.

En tercer lugar, la solución del derecho belga, en la que la fuerza mayor no suspende ni interrumpe el término de caducidad pero prorroga el cómputo del respectivo lapso, es una solución ajustada al ordenamiento jurídico colombiano que vale la pena tener en cuenta al momento de estudiar la oportunidad en la presentación de una demanda contenciosoadministrativa. Para comenzar, la solución en comento tiene un fundamento legal, en un principio general del derecho que ha sido consagrado expresamente en el artículo 64 del Código Civil -modificado por el artículo $1^{\circ}$ de la Ley 95 de 1890-: "Se llama fuerza mayor o caso fortuito el imprevisto a que no es posible resistir, como un naufragio, un terremoto, el apresamiento de enemigos, los actos de autoridad ejercidos por un funcionario público, etc.”. En nuestro derecho, la imposibilidad a la que obedece la fuerza mayor ha sido reconocida como un desarrollo del principio general ad impossibilianemoobligatur. Adicional a lo expuesto, la solución en comento se acompasa con el derecho nacional en razón a que, frente a las normas que establecen sanciones perentorias para el ejercicio de derechos subjetivos, dado lo inexorable de sus consecuencias jurídicas y en virtud misma de la seguridad jurídica y de la legalidad que persiguen proteger, debe ser posible que puedan sopesarse de forma equilibrada los intereses de las partes en relación con la naturaleza y el objeto del asunto. Lo anterior, para que sean evaluadas por el juez todas aquellas circunstancias sobrevinientes imprevisibles e irresistibles que imposibiliten el efecto que cualquier medida oportuna y razonable podría entrañar para la presentación oportuna de una demanda contencioso-administrativa.

En ese sentido, resulta criticable la interpretación restrictiva que la Sección Primera del Consejo de Estado le dio a la expresión “(...) ni aquellos en que por cualquier circunstancia permanezca cerrado el juzgado", establecida en el inciso final del artículo 118 del Código General del Proceso, en el auto arriba citado. Tal interpretación parece dejar de lado el hecho de que para el cómputo de los términos en meses y años existen situaciones análogas a las de clausura temporal del juzgado previstas para los términos en días, como la fuerza mayor, en las que no 72 
existe certeza sobre su comienzo, ni sobre su duración ni sobre su terminación. Y también parece soslayar que, según el artículo 12 del Código General del Proceso, las normas procesales deben aplicarse a casos análogos cuando la ley no regule expresamente dicha posibilidad $^{28}$. Nos referimos aquí, particularmente, a las situaciones de paro en la Rama Judicial. Queda claro que la finalidad de la norma es evitar que en los términos que son días las situaciones de cierre transitorio de los Despachos Judiciales -bien programada, como la vacancia judicial; bien con fundamento en razones del servicio, como, por ejemplo, la clausura del Despacho por cambio de Secretario- corran en perjuicio de quienes se ven afectados por lo corto de los lapsos legalmente previstos. Esto, contrario a lo que sucede, en teoría, con aquellos que son mucho más largos, de meses o años, en donde el accionante cuenta con mayores garantías para el ejercicio oportuno de sus derechos en los estrados judiciales y con mayor capacidad de reacción frente a sucesos que obstaculizarían el acceso a la administración de justicia.

Tampoco resulta de recibo la interpretación en comentoen el sentido en que, a diferencia de lo que considera la Sección Primera del Consejo de Estado,el último día de un paro judicial no puede equipararse a un día inhábil, a fin de que el vencimiento del término se extienda, como se pretende, equivocadamente, al primer día hábil siguiente. Allí existe completa incertidumbre acerca del día en que la administración de justicia retomará la prestación del servicio público en condiciones de normalidad, mientras que la certeza de la terminación del día inhábil está determinada por el calendario de cada año y por el artículo $1^{\circ}$ de la Ley 51 de 1983 ("Ley Emiliani”) para los festivos. De igual forma, el servicio de las Oficinas de Apoyo Judicial no se reincorpora de manera uniforme en todos los Despachos Judiciales de una misma ciudad ni del país, por lo que en unas especialidades jurisdiccionales pueden haberse reanudado labores de forma efectiva, mientras que en otras éstas pueden permanecer en cesación indefinida. Especialmente, según se recordará, dadas las tensiones que existieron en el último paro judicial entre ASONAL Judicial y la organización "El Vocero Judicial" sobre la suspensión o la revocatoria del Acuerdo No. PSAA-10445 de 16 de diciembre de 2015 (Ámbito Jurídico, 2015).

En efecto, hoy la interpretación de la previsibilidad y la posibilidad de resistir o no a la fuerza mayor, en tanto elementos fundamentales de la

28Artículo 12, Código General del Proceso: "Cualquier vacío en las disposiciones del presente código se llenará con las normas que regulen casos análogos. A falta de estas, el juez determinará la forma de realizar los actos procesales con observancia de los principios constitucionales y los generales del derecho procesal, procurando hacer efectivo el derecho sustancial" (El énfasis es mío). 
noción, se efectúa bajo criterios de justicia y equidad. Por ejemplo, en un derecho privado profundamente legalista como el belga, tratándose de la responsabilidad civil contractual, la doctrina ha considerado que "(...) la imposibilidad [de ejecución de la obligación ocasionada por la fuerza mayor] debe apreciarse de manera razonable y humana [sic]. (...) Es necesario, pero suficiente, que la ejecución sea normalmente imposible, teniendo en cuento las circunstancias y las condiciones de existencia (...). En todas las cosas, hay una medida a considerar. Esa medida es aquí la imposibilidad real normal de ejecución, y no la imposibilidad teórica absoluta de ello" (Wéry, 2014, 540). Otro tanto se ha dicho del examen de la previsibilidad en la responsabilidad civil extracontractual: aunque la previsibilidad del daño no hace parte, en sí misma de la causalidad, sino del hecho dañoso cuando la culpa no proviene de la infracción de un deber de cuidado expresamente previsto (distinto al neminemlaedere del artículo 1382 del Código Civil belga), sólo existe fuerza mayor cuando la posibilidad de la existencia del daño puede ser razonablemente anticipada por el autor, en su manifestación más primigenia, así se materialice de forma diferente, y éste no realiza efectivamente dicho esfuerzo para evitarlo (Storme, 1990).

Por supuesto, las circunstancias en las que permanezca cerrado un Despacho Judicial que no cuentan para el cómputo del plazo en meses y años -como sí para el cómputo en días hábiles- no se refieren, en ningún momento, a aquellas que serían constitutivas de fuerza mayor, como lo sería el paro judicial. Se trata de aquellas situaciones en donde el accionante puede determinar el momento exacto en que su demanda puede ser presentada en estrados, o cuando dicho momento es, a lo sumo, determinable. Es el caso, como lo anticipamos, del cierre de los Juzgados por cambio de Secretario o por cambio de sede. En la práctica, el impasse frente al paro judicial y la presentación de demandas ha sido resuelto por los litigantes recurriendo al artículo 23 del CPACA -modificado por el artículo $1^{\circ}$ de la Ley 1755 de 2015-. En esa disposición, se establece que "Los servidores de la Procuraduría General de la Nación, de la Defensoría del Pueblo, así como los personeros distritales y municipales, según la órbita de competencia, tienen el deber de prestar asistencia eficaz e inmediata a toda persona que la solicite, para garantizarle el ejercicio del derecho constitucional de petición. Si fuere necesario, deberán intervenir ante las autoridades competentes con el objeto de exigirles, en cada caso concreto, el cumplimiento de sus deberes legales. Así mismo recibirán, en sustitución de dichas autoridades, las peticiones, quejas, reclamos o recursos que aquellas se hubieren abstenido de recibir, y se cerciorarán de su debida tramitación" (El énfasis es mío). Lo anterior, teniendo en cuenta que, en principio, dicha 74 
norma sólo ha de aplicarse a las peticiones -recursos, quejas, reclamos o demás solicitados- que han de tramitarse en procedimientos administrativos. Sin embargo, ha sido la propia jurisprudencia contencioso-administrativa la que admitido que, en esas situaciones:

Aunque a la Personería no le corresponde recibir ni radicar demandas, para garantizar el derecho de acceso a la administración de justicia y por la situación excepcional de cierre de los despachos judiciales, se[haya tenido] como fecha de presentación de la demanda el día en que esa entidad la recibió(Consejo de Estado, 2014).

Todo esto resulta, por decir lo menos, desafortunado. En especial, para los derechos de los administrados. No es posible que sean las Personerías las que deban recibir las demandas contencioso-administrativas -actos procesales judiciales y no producidos en un trámite administrativoporque las Oficinas de Apoyo-entidades administrativas al servicio de la Rama Judicial- estarían cerradas por un paro judicial. La norma que les confiere tal competencia a las Personerías y que prevé tal situación de hecho no está prevista para cubrir los efectos negativos de las huelgas en la perturbación de un servicio público esencial como lo es el de la administración de justicia, sino, precisamente, para ofrecer una salida a la arbitrariedad de las autoridades administrativas en curso de un procedimiento administrativo. Mucho menos, que eso sea en razón a que los jueces contencioso-administrativos no podrían aceptar la existencia de un evento de fuerza mayor que atemperaría la perentoriedad del término de caducidad mediante su prórroga, puesto que cualquier situación por la que éstos se encuentren cerrados ha de interpretarse, según el órgano de cierre de la especialidad jurisdicción, como una que no justifica la modulación del término de caducidad, que se cuenta por lo general en meses y años -salvo el de ciertos eventos como la nulidad electoral y la nulidad de actos de adjudicación de baldíos, que es de 30 días-.

En conclusión, ante la perentoriedad de la sanción del término de caducidad, que como el curare de las flechas de ciertas tribunos indígenas de la Amazonía paraliza totalmente y torna en ineficaz el acceso a la administración de justicia por un paso del tiempo que se reputa objetivamente negligente, guardadas las proporciones, debe existir la cortapisa de la fuerza mayor como medida equitativa destinada a salvaguardar los derechos fundamentales de los justiciables. Sin embargo, contrario al terrible efecto inexorable de un veneno paralizante en la vida real, que no admite atemperaciones de ninguna clase sino 
antídotos que provean el efecto perfectamente contrario, en el derecho existe siempre una manera de hacer prevalecer la justicia para entregar la consecuencia jurídica de las normas aplicables bajo la consideración de las circunstancias propias de cada caso. A pesar de ser de orden público, la aplicación de los términos de caducidad admite atemperaciones y excepciones, siempre y cuando su interpretación favorable a la prevalencia del derecho sustancial no riña con el principio de legalidad ni con la seguridad jurídica y propugne por hacer efectivos los derechos de los usuarios de la justicia. Es por eso que la sanción de caducidad de los términos para interponer demandas ante los jueces y Tribunales administrativos debe estar matizada por la vis majorem como límite razonable mismo a cualquier arbitrariedad, en tanto principio general del derecho que permite superar, en cierta medida, verdades situaciones de imposibilidad física y material que darían al traste con el ejercicio del derecho de acción en la especialidad contencioso-administrativa, de no tenerse como justificación suficiente de la inactividad del demandante en reclamar en estrados sus derechos.

\section{REFERENCIAS BIBLIOGRÁFICAS}

Ámbito Jurídico. (2015). Retrieved marzo 27, 2017, from https://www.ambitojuridico.com/BancoConocimiento/Administrat ivo-y-Contratacion/el-nuevo-sindicato-de-la-rama-judicial-quedesafia-a-asonal

Caicedo Pérez, R. (2015, enero-junio). El derecho de huelga en Colombia: un sofisma. Revista Legem, 2 (2).

Consejo de Estado, 10239 (Sala de lo Contencioso Administrativo septiembre 4, 1997).

Consejo de Estado, 18805 (Sala de lo Contencioso Administrativo, Secc. Tercera noviembre 10,2000).

Consejo de Estado, 11326 (Sala de lo Contencioso Administrativo, Secc. Cuarta diciembre 1,2000).

Consejo de Estado, 25000-23-26-000-1995-00814-01(18273) (Sala de lo Contencioso Administrativo enero 29, 2004).

Consejo de Estado, 31135 (Sala de lo Contencioso Administrativo, Secc. Tercera julio 19, 2007). 
Consejo de Estado, 17811 (Sala de lo Contencioso Administrativo, Secc. Cuarta octubre 29, 2009).

Consejo de Estado, 2009-00078-01 (Sala de lo Contencioso Administrativo, Secc. Primera octubre 28, 2010).

Consejo de Estado, 15001-23-31-000-1998-00988-01(17064) (Sala de lo Contencioso Administrativo, Secc. Tercera enero 31, 2011).

Consejo de Estado, 27001-23-31-000-2009-00093-01 (Sala de lo Contencioso Administrativo, Secc. Primera agosto 4, 2011).

Consejo de Estado, 25000-23-26-000-2000-02151-01(26705) (Sala de lo Contencioso Administrativo, Secc. Tercera, Subsecc. "B" junio 26, 2014).

Consejo de Estado, 76001-23-33-000-2013-00330-01(20240) (Sala de lo Contencioso Administrativo, Secc. Cuarta marzo 27, 2014).

Consejo de Estado, 18001-23-33-000-2013-00298-01(AG) (Sala de lo Contencioso Administrativo, Secc. Tercera agosto 12, 2014).

Consejo de Estado, 76001-23-33-00-2013-00330-01(20240) (Sala de lo Contencioso Administrativo, Secc. Cuarta marzo 27, 2014).

Consejo de Estado, 25000-23-37-000-2013-00300-01(20273) (Sala de lo Contencioso Administrativo, Secc. Cuarta diciembre 4, 2014).

Consejo de Estado, 25000-23-37-000-2012-00387-01(20183) (Sala de lo Contencioso Administrativo mayo 7, 2014).

Consejo de Estado, 25000-23-26-000-2013-01547-01(49307) (Sala de lo Contencioso Administrativo, Secc. Tercera marzo 5, 2015).

Consejo de Estado, 25000-23-41-000-2013-01801-01 (Sala de lo Contencioso Administrativo, Secc. Primera febrero 19, 2015).

Consejo de Estado, 25000-23-41-000-2015-00155-01 (Sala de 1o Contencioso Administrativo, Secc. Primera agosto 31, 2015).

Consejo de Estado, 23001-23-33-000-2015-00112-01 (Sala de lo Contencioso Administrativo, Secc. Primera octubre 22, 2015). 
Consejo de Estado de Bélgica, 18.268 (Sección Administración mayo 12, 1977).

Consejo de Estado de Bélgica, 97.440 (Sección Administración julio 4, 2001).

Consejo de Estado de Bélgica, 111.442 (Sección ContenciosoAdministrativa octubre 11,2002).

Consejo de Estado de Bélgica, 116.499 (Sección Administración febrero $26,2003)$.

Consejo de Estado de Bélgica, 116.424 (Sección Administración febrero $25,2003)$.

Consejo de Estado de Bélgica, 146.940 (Sección ContenciosoAdministrativa junio 28, 2005).

Consejo de Estado de Bélgica, 161.216 (Sección ContenciosoAdministrativa julio 10,2006).

Consejo de Estado de Bélgica, 201.200 (Sección ContenciosoAdministrativa febrero 23, 2010).

Consejo de Estado de Bélgica, 214.402 (Sección ContenciosoAdministrativa julio 5, 2011).

Consejo de Estado de Bélgica, 234.575 (Sección ContenciosoAdministrativa abril 28, 2016).

Consejo de Estado de Bélgica, 234.035 (Sección ContenciosoAdministrativa marzo 4, 2016).

Cornelis, L. (2000). Algemene theorie van de verbintenis. Amberes: Intersentia.

Corte Constitucional, C-179 (abril 13, 1994).

Corte de Casación de Bélgica, Pas., 1981, 1, p. 369 (noviembre 28, 1980).

Corte de Casación de Bélgica, Pas., 1989, I, p. 135 (junio 2, 1989).

Corte de Casación de Bélgica, C.03.0601.F (febrero 10, 2005). 
Corte de Casación de Bélgica, C.08.0323.F/2 y C.09.0590.F (marzo 16, 2012).

Corte Suprema de Justicia, G.J. No. MMCCCXCIII, p. 497 (Sala de Casación Civil 11 19, 1976).

Corte Suprema de Justicia, 6630 (Sala de Casación Civil junio 16, 1997).

Corte Suprema de Justicia, 48496 (SLL13430-2016) (Sala de Casación Laboral septiembre 14, 2016).

Duque Sánchez, L. C. (2012). Acción de repetición en Colombia: una tarea pendiente en la administración pública. Revista Jurídica de la Universidad de Caldas, 1 (9).

Englebert, J., Boularbah, H., y Van Drooghenbroeck, J.-F. (2015). Audience-Judiciaire 2015-2016. Bruselas: Groupe Larcier.

Fonseca Jaramillo, C. (2004, Enero). La prescripción extintiva y la caducidad. (31).

Goffaux, P. (2008). Le régime juridique des recours administratifs inorganisés et organisés. Revue de droit de l'Université Libre de Bruxelles (37).

Jafferali, R. (2016). Prendre la caducité par disparition de l'objet au sérieux. In

R. Jafferali (Ed.), Le droit commun des contrats: questions choisies. Bruselas: Bruylant.

Jeuland, E., y Charbonneau, C. (2010). Reálité des délais de forclusion. In P.

Jourdain y P. Wéry (Eds.), La prescription extinctive : études de droit comparé. Bruselas: Bruylant.

Leroy, M. (2011). Contentieux administatif. Bruselas: Anthemis, Université Libre de Bruxelles.

Lewalle, P., y Donnay, L. (2008). Contentieux administratif. Bruselas: Groupe Larcier. 
Noël, M.-P. (2010). Les délais préfix. In P. Jourdain y P. Wéry (Eds.), La prescription extinctive : études de droit comparé. Bruselas: Bruylant.

Renders, D. (2017). Code administratif2017. Bruselas: Bruylant.

Renders, D. (2015). Droit administratif général. Bruselas: Bruylant.

Renders, D., Bombois, T., Gors, B., Thiebaut, C. y Vansnick, L. (2010). Droit administratif, T. III : Le contrôle de l'administration. Bruselas: Groupe Larcier.

Rouvière, F. (2009). La distinction entre délais de prescription, butoir et de

forclusion. Petites Affiches .

Storme, M. E. (1990). Quelques aspects de la causalité en droit des obligations et des assurances. Retrieved febrero 26, 2017, from https://www.law.kuleuven.be/personal/mstorme/causalite.pdf

Torres Calderón, L. (2005, junio). ¿Se justifica la acción de repetición? Revista Civilizar .

Tulkens, F., Vandermeersch, D. y Beernaert, M.-A. (2016). Code pénal. Bruselas: Bruylant.

Van Drooghenbroeck, J.-F. (2016). Droit judiciaire 2016-2017. Louvain-la-Neuve: Université Catholique de Louvain.

Van Ommeslaghe, P. (1979). Rechtsverwerking en afstand van recht. Preadvies uitgebracht op de Jaarvergadering van de Verniging voor verlijking van het Recht in België en Nederland op 23 novembre 1979. Amberes.

Van Ommeslaghe, P. (2013). Traité de droit civil belge, Tomo II (Vol. 1 a 3). Bruselas: Bruylant.

Wéry, P. (2014). Droit des obligations. Précis de l'Université Catholique de Louvain. Bruselas: Groupe Larcier. 